\title{
Bio-Oil Production by Thermal Cracking in the Presence of Hydrogen
}

\author{
Renato Cataluña ${ }^{1 *}$, Zeban Shah $^{2}$, Pedro Motifumi Kuamoto ${ }^{3}$, Elina B. Caramão ${ }^{4}$, Maria \\ Elisabete Machado ${ }^{5}$, Rosangela da Silva ${ }^{6}$
}

\author{
${ }^{1,2,3,4,5}$ Federal University of Rio Grande do Sul, Av. Bento Gonçalves 9500, 91501-970 Porto Alegre, RS, Brazil \\ ${ }^{6}$ Pontifical Catholic University of Rio Grande do Sul, Av. Ipiranga 6681, 90619-900 Porto Alegre, RS, Brazil
}

\begin{abstract}
This paper describes the bio-oil production process of a mixture of agricultural wastes: discarded soybean frying oil, coffee and sawdust, by pyrolysis and thermal cracking in the presence of hydrogen. The fractions obtained in the pyrolysis and/or cracking processes were divided into a light fraction and a heavy one. All the fractions were analyzed by comprehensive two-dimensional gas chromatography with time-of-flight mass spectrometry detection $(G C \times G C / T O F M S)$. The characteristics of the fractions obtained in the cracking process in the presence of hydrogen were similar to those of petroleum-based naphtha, while the fractions obtained by pyrolysis contained significant quantities of compounds such as furanmethanol, hexanol, and benzofuran, whose commercial value is high.
\end{abstract}

Keywords-Biomass pyrolysis, Chromatography, Hydrogen, Thermal cracking.

\section{INTRODUCTION}

The recent environmental restrictions on the use of fossil fuels have intensified research into new alternative energy sources. Many alternative technologies to produce cleaner fuels have been developed, including the use of biomass, which offers a promising potential [1-4].

Biomass is a renewable source which has received attention due to various characteristics, particularly its low cost and wide availability. Biomass can be converted into bio-fuel by means of different processes, e.g., reductive combustion, liquefaction, pyrolysis and gasification [5]. The use of biomass is particularly interesting when it involves waste products such as waste vegetable oil, fruit seeds, sugarcane bagasse, sugarcane straw, rice husks, coconut fibers, and coffee grounds, which are also potential sources of energy [6-8].

Bio-oil from biomass pyrolysis, also known as pyrolysis oil, is a dark brown almost black liquid with a characteristic smoky odor, whose elemental composition is analogous to that of the biomass from which it derives. It is a complex mixture of oxygenated compounds with a significant amount of water originating from the moisture of the biomass and from cracking reactions. Bio-oil may also contain small coal particles and dissolved alkali metals coming from the ash. Its composition depends on the raw material and on the operating conditions used in its production. Pyrolysis oil is an aqueous microemulsion resulting from the products of fragmentation of cellulose, hemicellulose and lignin [9-10].

Much attention has focused on pyrolysis, a biomass thermal decomposition process, for which the literature describes numerous different reactors and conditions [11-13]. The presence of oxygen exerts a highly negative impact on the potential uses for bio-oil. For example, oxygen lowers the heating value, gives rise to immiscibility with petroleum fuels, and leads to corrosiveness and instability during long-term storage and transportation [14]. The biomass pyrolysis process is an economically feasible option for producing chemicals and/or fuels [15,16]. The bio-oil resulting from the pyrolysis process consists of a mixture of more than 300 organic compounds [17], but its processing, separation and characterization pose technological challenges. In the thermal cracking process, the volatile compounds generated during pyrolysis also present a promising potential for energy generation [18]. Moreover, the upgrading process, which involves the reduction of oxygenates and is necessary to improve the quality of bio-oil, normally requires processes such as catalytic cracking, hydrogenation and steam reforming [9-22].

Hydropyrolysis is an important technique for improving the quality of bio-oil produced from biomass pyrolysis. Hydrogen is a reducing gas and cracking biomass in the presence of hydrogen can reduce the oxygen content in bio-oil [23]. This paper discusses the characterization of bio-oil generated from the pyrolysis of a mixture of wastes: discarded soybean frying oil, coffee grounds and sawdust. The thermal cracking process, which was performed in the presence of hydrogen in order to 
upgrade the bio-oil, resulted in lower molecular weight fractions and substantially reduced the content of oxygenated and nitrogenated species.

\section{EXPERIMENTAL}

\subsection{Materials}

The bio-oil was obtained by pyrolysis of a mixture (1:1:1, in mass) of wastes: discarded soybean frying oil, coffee grounds and eucalyptus sawdust. The frying oil was mixed with the solids after their particle size was reduced to $0.21 \mathrm{~mm}$. To this mixture were added calcium oxide (20 mass \%) and sufficient water to produce a malleable mass that could be molded into cylindrical samples $(50 \mathrm{~mm} \times 180 \mathrm{~mm})$. The samples were allowed to dry at room temperature for a week.

\subsection{Biomass pyrolysis and thermal cracking of the bio-oil}

The bio-oil was produced by conventional pyrolysis of the cylindrical samples in an electrically heated stainless steel reactor. Before beginning the pyrolysis, the system was purged for 20 minutes with Argon containing 5\% of hydrogen $\left(100 \mathrm{~mL} \mathrm{~min}^{-1}\right)$. After purging, the pyrolysis started and the system was heated to $850{ }^{\circ} \mathrm{C}$ at a heating rate of $15^{\circ} \mathrm{C} \mathrm{min}{ }^{-1}$. The volatiles produced during the process were treated by isothermal hydrocracking in another reactor (stainless steel, $20 \mathrm{~mm}$ in diameter and $600 \mathrm{~mm}$ in length) at $850{ }^{\circ} \mathrm{C}$. The final effluent was cooled to $100{ }^{\circ} \mathrm{C}$ and the water phase was separated by decantation.

After phase separation, the effluent was condensed at $5{ }^{\circ} \mathrm{C}$ and the aqueous phase separation process was repeated, while the gaseous phase was discarded.

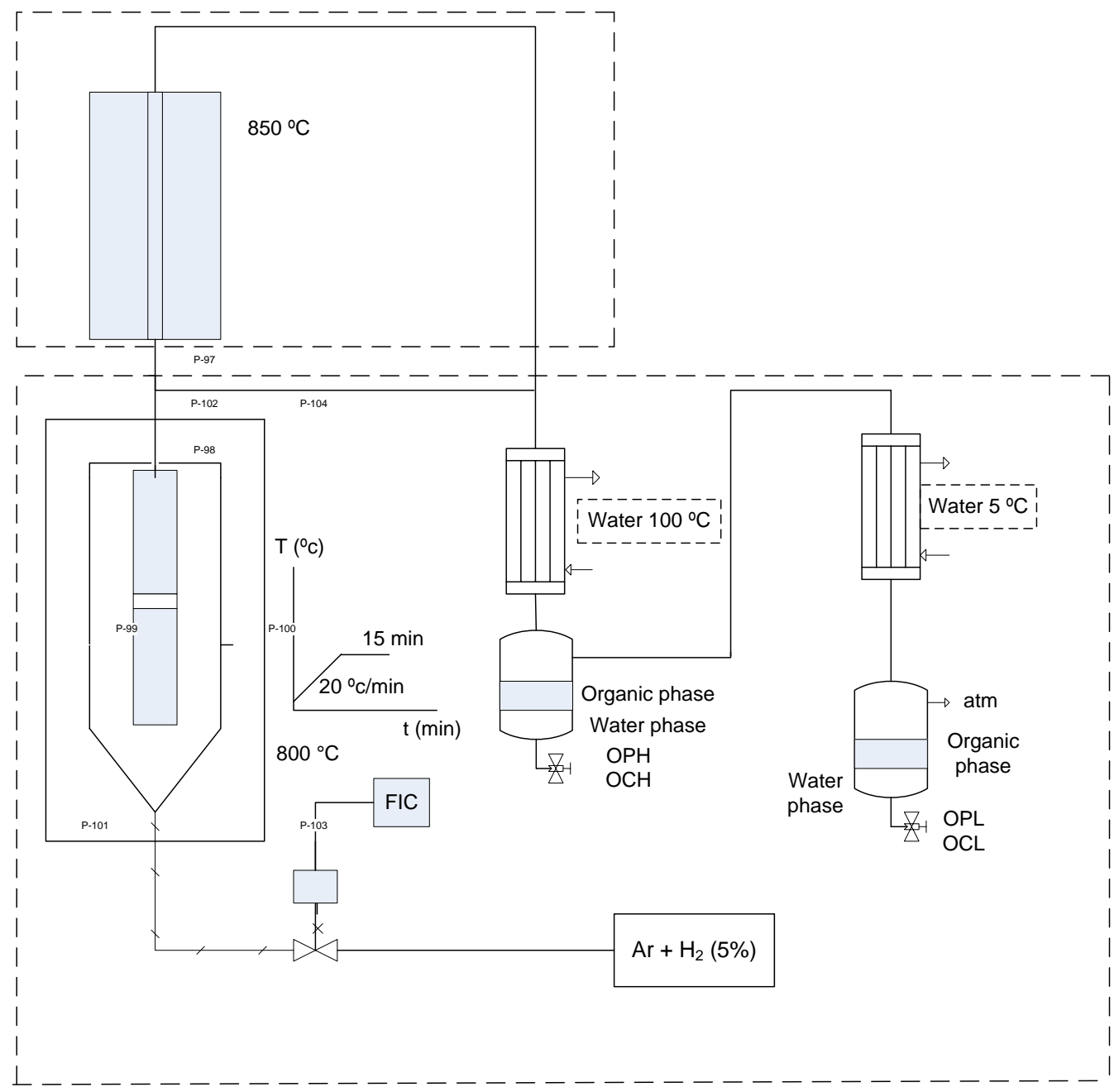

Figure 1. PRODUCTION SCHEME OF THE FOUR FRACTIONS PRODUCED: OPH AND OPL BY THE PYROLYSIS PROCESS AND OCH AND OCL BY THE PYROLYSIS PROCESS FOLLOWED BY THERMAL CRACKING. 
For purposes of comparison, the pyrolysis was repeated without thermal cracking. Four samples were thus produced: bio-oil obtained at $100{ }^{\circ} \mathrm{C}$, and bio-oil obtained at $5{ }^{\circ} \mathrm{C}$, both with and without thermal cracking. These samples are hereinafter referred to as: $\mathrm{OPH}$ (Oil from Pyrolysis obtained at $100{ }^{\circ} \mathrm{C}-$ High temperature) and OPL (Oil from Pyrolysis obtained at $5^{\circ} \mathrm{C}$ - Low temperature) for samples obtained only by pyrolysis, and $\mathrm{OCH}$ (Oil after Cracking obtained at $100^{\circ} \mathrm{C}-\mathrm{High}$ temperature) and OCL (Oil after Cracking obtained at $5^{\circ} \mathrm{C}$ - Low temperature) for those obtained after thermal cracking. Fig 1 illustrates the production scheme of the four fractions produced, i.e., OPH and OPL by the pyrolysis process and OCH and OCL by the pyrolysis process followed by thermal cracking.

\subsection{Characterization of the products}

The four fractions were analyzed by GC×GC/TOFMS using a LECO Pegasus IV (LECO, St Joseph, MI, USA) system. Experiments were performed in a conventional split/splitless injector (Agilent Technologies) at $320{ }^{\circ} \mathrm{C}(1 \mu \mathrm{L})$ with a split ratio equal to 1:30. Helium (99.999\%, Linde Gases, Porto Alegre, RS, Brazil) was used as carrier gas, at $1 \mathrm{~mL} \mathrm{~min}^{-1}$. The oven temperature was programmed from $40{ }^{\circ} \mathrm{C}$ to $300{ }^{\circ} \mathrm{C}$ at $3{ }^{\circ} \mathrm{C} \mathrm{min}{ }^{-1}$. The difference between ovens $1 \mathrm{D}$ and $2 \mathrm{D}$ was $15{ }^{\circ} \mathrm{C}$ and the modulation period was $8 \mathrm{~s}$ (cryogenic quadjet modulator, cooled with liquid nitrogen). The transfer line and electron impact ionization source operated at $300{ }^{\circ} \mathrm{C}$ and $250{ }^{\circ} \mathrm{C}$. The acquisition frequency of the detector was $100 \mathrm{~Hz}$, using a mass range of 45 to 400 Daltons. Electron ionization was carried out at $70 \mathrm{eV}$. The data were processed on the Pegasus $4 \mathrm{D}$ platform of the ChromaTOF software. A DB-5 column was used as first dimension, and a DB-17 as second dimension column, using a cryogenic modulator.

The compounds were identified based on the following parameters: retention times, regions of spatial structuration, mass spectral match factor (NIST library), and spectral deconvolution. Given the spatial structure provided by GC $\times$ GC, some compounds with similarity below 700 were considered to be identified, since the elution region in the two-dimensional (2D) space, as well as other parameters, provide a higher degree of reliability in the identification of analytes. The data generated in the peak table were transferred to the Microsoft Excel ${ }^{\mathrm{TM}}$ program in order to build dispersion graphics to better visualize the distribution of compounds in 2D space.

\section{RESULTS AND DISCUSSION}

\subsection{Product yields from pyrolysis and thermal cracking}

Pyrolysis product distribution depends on reaction parameters such as temperature, heating rate and reactant particle size, as well as on the starting biomass.

The oil fractions obtained in this work came from the same raw materials and the same operational conditions, but from different production processes. The OCH sample was obtained by pyrolysis followed by thermal cracking, while the OPH sample was obtained solely by pyrolysis. The application of thermal cracking after pyrolysis led to a significant increase in the condensed fraction at the temperature of $5{ }^{\circ} \mathrm{C}$. The average yield of the pyrolysis process is approximately $30 \%$ oil fractions, $50 \%$ aqueous fractions, and $20 \%$ gas phase (uncondensed, obtained by difference). In the pyrolysis process, the oil fraction condensed at a temperature of $100{ }^{\circ} \mathrm{C}$ corresponds to approximately $90 \%$ of the oil fraction. Pyrolysis followed by thermal cracking results in a distribution of approximately $40 \%$ of the fraction condensed at a temperature of $5{ }^{\circ} \mathrm{C}(\mathrm{OCL})$ and $60 \%$ of the oil fraction condensed at a temperature of $100{ }^{\circ} \mathrm{C}(\mathrm{OCH})$.

\subsection{Composition of bio-oil fractions}

Given that the four bio-oil fractions are very complex mixtures of different chemical species derived from depolymerization and fragmentation of the main components of the biomass, which comprise a wide range of molecular weights, a GCXGC/TOFMS was used for their identification.

The compositions of the four bio-oil fractions shown in Fig 2 are grouped according to types of chemical compounds: acids, aldehydes, ketones, alcohols, phenols, aromatics, cyclic and aliphatic hydrocarbons, ethers and nitrogen compounds. The compounds were tentatively identified when the similarity between a sample's spectrum and that of the library was greater than 750. In total, 214 compounds in $\mathrm{OCH}, 324$ in OCL, 84 in OPH and 312 in OPL were tentatively identified.

Some observations apply both to the bio-oils obtained from thermal degradation and to the light fraction of pyrolysis (OPLFig 2). For example, note that there is a high proportion of hydrocarbon compounds, the most important ones being aromatics and aliphatics, representing between 57 and $79 \mathrm{wt} \%$ of the products. On the other hand, the OPH sample obtained by pyrolysis and condensed at $100{ }^{\circ} \mathrm{C}$ (fraction containing heavy compounds) is composed mainly of ketones and nitrogens, and 
smaller amounts of alcohols, ethers and phenols. This fraction does not contain hydrocarbons. Nitrogenous compounds in bio-oil originate from the thermal degradation of caffeine derivatives contained in coffee grounds.

As can be seen in Fig 2, the fractions obtained by pyrolysis and thermal cracking (OCH and OCL) consist mostly of aliphatic, aromatic and cyclic hydrocarbons. The OPH fraction is composed mainly of hydrocarbons with nitrogen (46\% in area) and oxygen (47\% in area) compounds. The oxygen content in pyrolysis bio-oils usually varies from 45 to $50 \mathrm{w} / \mathrm{w} \%$, and oxygen is present in most of the more than 300 compounds [10, 24-25]. The distribution of these compounds depends mainly on the type of biomass and the process conditions. The presence of oxygenated compounds in bio-oil reduces its calorific value and renders it chemically unstable [9], limiting its use as fuel or in formulations for direct use in diesel cycle engines [9, 26-27]. However, when separated, they present high added commercial value [28].

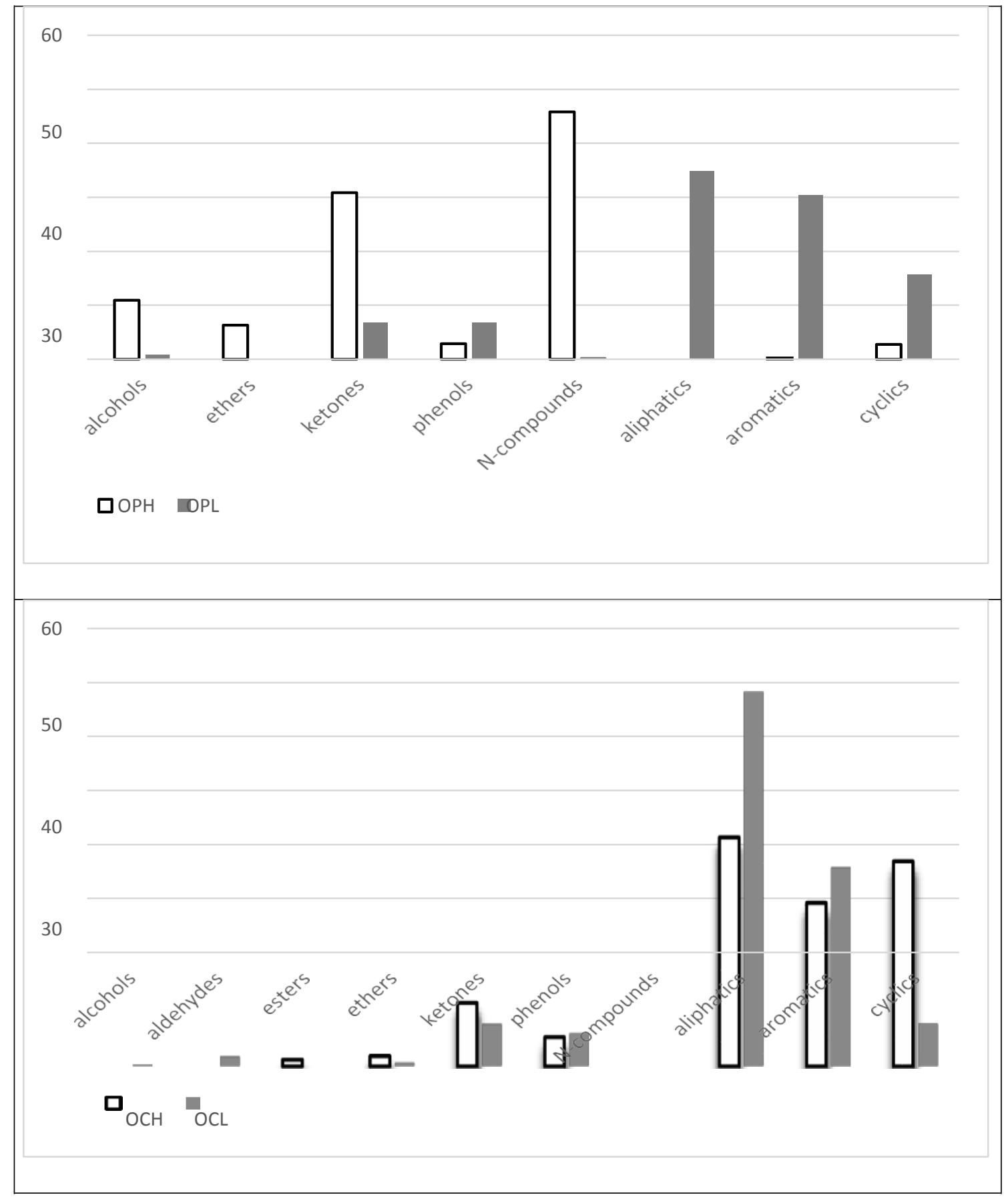

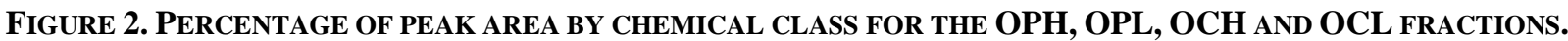


Table 1 lists the main identified compounds and their corresponding percentage area in the bio-oil and fractions (OPH, OPL, $\mathrm{OCH}$ and $\mathrm{OCL})$. The other compounds contained in the fractions of this study are listed in the Appendix.

As can be seen in Table 1, the oxygenated compounds in the OPH fraction alcohols include furanmethanol (8\% in area) and hexanol (2\% in area). These two alcohols are important raw materials for the preparation of a wide range of drugs and industrial products of high commercial and industrial value [29]. Benzofuran and dioxyethane ethers are also present in the $\mathrm{OPH}$ fraction in percentage areas of 4.0 and 2.0, respectively. Benzofuran is considered an important class of heterocyclic compounds which is present in numerous bioactive natural products and in pharmaceuticals and polymers. Benzofuran is one of the most important heterocyclic rings due to its broad microbiological range. Medicinal chemistry is widely involved in the synthesis of the benzofuran ring owing to its clinical importance. Benzofuran can be used as an enzyme activator and inhibitor, as an antimicrobial, anti-inflammatory, anti-cancer, antiviral, anti-tuberculosis, antioxidant agent, etc. [30].

TABLE 1

MAIN IDENTIFIED COMPOUNDS AND THEIR CORRESPONDING PERCENTAGE AREA IN THE BIO-OIL AND FRACTIONS (OPH, OPL, OCH AND OCL)

\begin{tabular}{|c|c|c|c|c|c|}
\hline \multirow{2}{*}{\multicolumn{2}{|c|}{ major compounds }} & \multicolumn{4}{|c|}{ area $\%$} \\
\hline & & \multirow{2}{*}{$\frac{\text { OCH }}{\text { n.d. }}$} & \multirow{2}{*}{$\frac{\text { OPL }}{\text { n.d. }}$} & \multirow{2}{*}{$\frac{\text { OCL }}{\text { n.d. }}$} & \multirow{2}{*}{$\begin{array}{r}\text { OPH } \\
8.4\end{array}$} \\
\hline alcohol & Furanmethanol & & & & \\
\hline & Hexanol & n.d. & 0.2 & n.d. & 2.3 \\
\hline aldehyde & Propenal, phenyl & n.d. & 0.1 & 1.1 & n.d. \\
\hline \multirow{2}{*}{ ether } & Benzofuran & 0.5 & n.d. & 0.1 & 4.3 \\
\hline & Ethane, diethoxy- & n.d. & n.d. & n.d. & 2.0 \\
\hline \multirow{8}{*}{ ketone } & Hexadecanone & 1.5 & n.d. & n.d. & n.d. \\
\hline & Nonanone & n.d. & n.d. & 1.4 & n.d. \\
\hline & Cyclopentenone, methyl- & n.d. & n.d. & n.d. & 6.6 \\
\hline & Cyclopentenone, C3 & 0.2 & 0.5 & 0.2 & 6.2 \\
\hline & Cyclopentenone, C2 & 0.1 & 0.4 & n.d. & 5.6 \\
\hline & Cyclohexenone, methyl- & n.d. & 0.2 & n.d. & 1.7 \\
\hline & Cyclopentanone & n.d. & 0.1 & 0.1 & 1.2 \\
\hline & Cyclopentanone, methyl & n.d. & 0.3 & 0.1 & 1.1 \\
\hline \multirow{8}{*}{$\mathrm{N}$-compound } & Pyrrole, methyl- & n.d. & n.d. & n.d. & 9.3 \\
\hline & Pyrazine, C5 & n.d. & n.d. & n.d. & 8.1 \\
\hline & Pyrazine, C3 & n.d. & n.d. & n.d. & 2.8 \\
\hline & Pyrazole, C4 & n.d. & n.d. & n.d. & 1.7 \\
\hline & Imidazole, C5 & n.d. & n.d. & n.d. & 1.6 \\
\hline & Pyrazine, C4 & n.d. & n.d. & n.d. & 1.5 \\
\hline & Pyridine, methyl- & n.d. & n.d. & n.d. & 1.4 \\
\hline & Pentanamide, methyl- & n.d. & n.d. & n.d. & 1.0 \\
\hline \multirow{3}{*}{ phenol } & Phenol, ethyl & 1.7 & 1,4 & 1.1 & n.d. \\
\hline & Phenol, methyl- & n.d. & 1.9 & n.d. & 0.1 \\
\hline & Phenol & 0.3 & 0.6 & 1.0 & 2.0 \\
\hline
\end{tabular}




\begin{tabular}{|c|c|c|c|c|c|}
\hline \multirow{2}{*}{ class } & \multirow{2}{*}{ identification } & \multicolumn{4}{|c|}{ area $\%$} \\
\hline & & OCH & OPL & OCL & OPH \\
\hline \multirow{6}{*}{ HC cyclic-C5 } & Cyclopentadiene, $\mathrm{C} 2$ & 2.6 & n.d. & n.d. & n.d. \\
\hline & Cyclopentadiene, methyl & 2.1 & n.d. & n.d. & n.d. \\
\hline & Cyclopentadiene, C3 & 1.2 & n.d. & n.d. & n.d. \\
\hline & Cyclopentene, C6 & n.d. & 1.2 & n.d. & n.d. \\
\hline & Cyclopentane, C8 & n.d. & n.d. & 1.1 & n.d. \\
\hline & Cyclopentadiene, C5 & n.d. & n.d. & n.d. & 2.2 \\
\hline \multirow{4}{*}{ HC cyclic-C6 } & Cyclohexene, C2 & 4.2 & 0.1 & n.d. & n.d. \\
\hline & Cyclohexene, methyl & 5.1 & 0.2 & 0.5 & n.d. \\
\hline & Cyclohexadiene, C2 & 4.7 & 0.4 & 0.4 & n.d. \\
\hline & Cyclohexadiene, C4 & n.d. & 1.1 & n.d. & n.d. \\
\hline \multirow{23}{*}{ HC diaromatic } & Indene, methyl & 1.3 & 1.2 & 1.3 & n.d. \\
\hline & Indene, $\mathrm{C} 2$ & 1.1 & n.d. & n.d. & n.d. \\
\hline & indene & n.d. & 2.4 & 1.4 & n.d. \\
\hline & Naphthalene, dihydro- & n.d. & 1.8 & n.d. & n.d. \\
\hline & Indane & n.d. & 1.0 & 0.5 & n.d. \\
\hline & Naphthalene, methyl & n.d. & 0.6 & 1.1 & n.d. \\
\hline & Heptadiene & 2.4 & n.d. & 0.6 & n.d. \\
\hline & Dodecadiene & n.d. & 1.3 & n.d. & n.d. \\
\hline & Toluene & 6.2 & 1.0 & 0.1 & 0.2 \\
\hline & Benzene & 2.1 & n.d. & 2.1 & n.d. \\
\hline & Benzene, C3 & 3.9 & 2.0 & 3.4 & n.d. \\
\hline & Benzene, C4 & 1.0 & 3.4 & 1.9 & n.d. \\
\hline & Benzene, C5 & 0.1 & 1.3 & 0.3 & n.d. \\
\hline & Benzene, C2 & n.d. & 1.1 & 6.3 & n.d. \\
\hline & octene & 2.9 & 2.7 & 1.3 & n.d. \\
\hline & decene & 1.3 & n.d. & 1.0 & n.d. \\
\hline & dodecene & n.d. & 1.7 & 1.0 & n.d. \\
\hline & undecene & 0.6 & 1.2 & 0.6 & n.d. \\
\hline & octane & 6.9 & 1.7 & 0.4 & n.d. \\
\hline & nonane & 1.0 & n.d. & 1.5 & n.d. \\
\hline & tridecane & 0.4. & 4.4 & 1.1 & n.d. \\
\hline & pentadecane & 0.6 & 1.2 & 0.8 & n.d. \\
\hline & docecane & 03 & 1.0 & 0.5 & n.d. \\
\hline
\end{tabular}

The four fractions of this study contained phenolic compounds, namely, around 7\% OPL, 4\% OCH and OCL, and 3\% OPH. These compounds are widely employed in the production of phenolic resins [31]. They also have antioxidant and antimicrobial properties that inhibit the proliferation of microorganisms, corrosion and deposits when added to diesel fuel formulations and/or biodiesel for use in engines (use of biomass-derived compounds) [32-33].

Moreover, chemical products containing oxygen are produced mainly from fossil fuels, through the oxidation or hydration of olefins to introduce oxygen containing functional groups. Fortunately, these functional groups are already present in bio-oil. Therefore, obtaining value-added chemicals from bio-oil is a potential approach for the efficient use of biomass energy.

With respect to the $\mathrm{N}$-compounds present only in the $\mathrm{OPH}$ fraction, pyrazines corresponded to $25 \%$ in area. Pyrazine is an important product that participates together with benzene in the synthesis of quinoxaline, also known as benzopyrazine, which is rare in its natural state, but is easy to synthesize. Quinoxaline and its derivatives are very industrially important because of their ability to inhibit metal corrosion [34] in the preparation of porphyrins [35]. The pharmaceutical industry has a potential interest in them because of their broad spectrum of biological properties [36-38].

The composition of the OPH fraction contained practically no aromatic hydrocarbons. On the other hand, the OPL, OCH and OCL fractions each presented approximately $16 \%$ in area of alkylbenzenes, which could be isolated and, together with the pyrazines of the $\mathrm{OPH}$ fraction, serve as raw material for the synthesis of quinoxaline and its derivatives. 
The OCL and OCH fractions obtained by thermal cracking in the presence of a mixture of argon and 5\% hydrogen resulted in the elimination of oxygen (deoxygenation) with the formation of water [39], and a stronger breakdown of the heavier organic compounds into lighter organic compounds, as well as the elimination of nitrogen from the nitrogenated compounds. This is illustrated in Fig 2 and in the supplementary material. Because thermal cracking produces various fragments of C-C, they may undergo oligomerization to form olefins, which in turn may undergo aromatization followed by alkylation and isomerization, producing aromatics.

The OCH and OCL fractions presented percentage areas of 82 and 84, respectively, of these hydrocarbons. The OPL fraction obtained by pyrolysis showed a profile similar to that of the OCH and OCL fractions with respect to hydrocarbons, with $81 \%$ in area, but with $8.0 \%$ of oxygenated compounds.

\section{CONCLUSION}

In the fractions obtained by pyrolysis, 84 compounds were tentatively identified in the heavy fraction and 312 in the light fraction. The vapors were subjected to thermal cracking in the presence of 5\% hydrogen as a way to upgrade the bio-oil, and 214 compounds were identified in the heavy fraction and 324 in the light fraction. The thermal cracking process produced mainly aliphatic, aromatic and cyclic hydrocarbons, yielding approximately $80 \%$ in weight of these compounds with characteristics similar to those of naphtha derived from the atmospheric distillation of petroleum with potential applications as fuels. The fractions obtained solely by pyrolysis consisted predominantly of hydrocarbons with nitrogen (46\% in area) and oxygen (47\% in area) compounds. The oxygenated compounds included furanmethanol and hexanol alcohols, and benzofuran and dioxyethane ethers. All the analyzed fractions contained phenolic compounds. When isolated, these compounds are an excellent potential source of raw material for the preparation of pharmaceutical and industrial products of high commercial and industrial value.

\section{ACKNOWLEDGEMENTS}

The authors want to tkank CNPq.

\section{REFERENCES}

[1] S. Arbogast, D. Bellman, J. D. Paynter and J. Wykowski, “Advanced bio-fuels from pyrolysis oil: The impact of economies of scale and use of existing logistic and processing capabilities," Fuel Processing Technology, vol. 104, pp. 121-127, 2012.

[2] S. Arbogast, D. Bellman, J. D. Paynter and J. Wykowski, “Advanced biofuels from pyrolysis oil... Opportunities for cost reduction," Fuel Processing Technology, vol. 106, pp. 518-525, 2013.

[3] A. A. Khan, W. Jong, P. J. Jansens and H. Spliethoff, "Biomass combustion in fluidized bed boilers: Potential problems and remedies," Fuel Processing Technology, vol. 90, pp. 21-50, 2009.

[4] R. Cataluña, P. M. Kuamoto, C. L. Petzhold, E. B. Caramão, M .E. Machado and R. Silva, "Using Bio-oil Produced by Biomass Pyrolysis as Diesel Fuel,” Energy Fuels, vol. 27, pp. 6831-6838, 2013.

[5] N. Laksmono, M. Paraschiv, K. Loubar and M. Tazerout, "Biodiesel production from biomass gasification tar via thermal/catalytic cracking," Fuel Processing Technology, vol. 106, pp. 776-783, 2013.

[6] M. H. Dukua, S. Gu and E. B. Hagan, "A comprehensive review of biomass resources and biofuels potential in Ghana," Renewable and Sustainable Energy Reviews, vol. 15, pp. 404-415, 2011.

[7] http://www.unep.org/ietc/Portals/136/Publications/Waste\%20Management/WasteAgriculturalBiomassEST_Compendium.pdf

[8] E. Virmond, J. D. Rocha, R. F. P. M. Moreira and H. J. José, "Valorization of agroindustrial solid residues and residues from biofuel production chains by thermochemical conversion: a review, citing Brazil as a case study," Brazilian Journal of Chemical Engineering, vol. 30, pp. 197-229, 2013.

[9] A. V. Bridgwater, "Biomass fast pyrolysis," Thermal science, vol. 8, pp. 21-49, 2004.

[10] A. V. Bridgwater, "Biomass Pyrolysis - an overview prepared by Task 34" In: TUSTIN, J., IEA Bioenergy Annual Report 2006, www.ieabioenergy.com

[11] D. Mohan, C. U. Pittman and P. H. Steele, "Pyrolysis of wood/biomass for bio- oil: a critical review," Energy Fuel, vol. 20, pp. 848$889,2006$.

[12] S. Li, S. Xu, S. Liu, C. Yang and Q. Lu, "Fast pyrolysis of biomass in free-fall reactor for hydrogen-rich gas," Fuel Processing Technology, vol. 85, pp. 1201- 1211, 2004.

[13] N. Özbay, B. B. Uzun, E. A. Varol and A. E. Pütün, "Comparative analysis of pyrolysis oils and its subfractions under different atmospheric conditions,” Fuel Processing Technology, vol. 87, pp. 1013-1019, 2006.

[14] B. Girisuta, K. G. Kalogiannis, K. Dussan, J. J. Leahy, M. H. B. Hayes, S. D. Stefanidis, C. M. Michailof and A. A. Lappas, "An integrated process for the production of platform chemicals and diesel miscible fuels by acid-catalyzed hydrolysis and downstream upgrading of the acid hydrolysis residues with thermal and catalytic pyrolysis," Bioresource Technology, vol. 126, pp. 92-100, 2012. 
[15] T. P. Vispute, H. Zhang, A. Sanna, R. Xiao and G. W. Huber, "Renewable chemical commodity feedstocks from integrated catalytic processing of oils," Science, vol. 330, pp. 1222-1227, 2010.

[16] M. M. Wright, D. E. Daugaard, J. A. Satrio and R. C. Brown, "Techno-economic analysis of biomass fast pyrolysis to transportation fuels," Fuel, vol. 89, pp. 52-510, 2010.

[17] R. Mythili, P. Venkatachalam, P. Subramanain and D. Uma, "Characterization of bioresidues for bioil production through pyrolysis," Bioresource Technology, vol. 138, pp. 71- 78, 2013.

[18] P. M. Mortensen, J. D. Grunwaldt, P. A. Jensen, K. G. Knudsen and A.D. Jensen, "A review of catalytic upgrading of bio-oil to engine fuels," Applied Catalysis A: General, vol. 407, pp. 1-19, 2011.

[19] X. F. Zhu, J. L. Zheng, Q. X. Guo and Q. S. Zhu, "Upgrading and utilization of bio-oil from biomass," Engineering Science, vol. 7, pp. 83-88, 2005.

[20] Q. Zhang, Q. J. Chang, T. J. Wang and Y. Xu, "Progress on research of properties and upgrading of bio-oil." Petrochemical Technology, vol. 35, pp. 493-498, 2006.

[21] X. Y. Guo, Y. J. Yan and T. C. Li, "Influence of catalyst type and regeneration on upgrading of crude bio-oil through catalytical thermal cracking," The Chinese Journal of Process Engineering, vol. 4, pp. 53-58, 2004.

[22] P. K. Kanaujia, Y. K. Sharma, M. O. Garg, D. Tripathi and R. Singh, "Review of analytical strategies in the production and upgrading of bio-oils derived from lignocellulosic biomass," Journal of Analytical and Applied Pyrolysis, vol. 105, pp. 55-74, 2014.

[23] S. Thangalazhy-Gopakumar, S. Adhikari, R. B. Gupta, M. Tu and S. Taylor, "Production of hydrocarbon fuels from biomass using catalytic pyrolysis under helium and hydrogen environments," Bioresource Technology, vol. 102, pp. 6742-6749, 2011.

[24] D. Meier, A. Oasmaa and G. V. C. Peacocke, "Proper ties of Fast Pyrolysis Liquids: Status of Test Methods. Characterization of Fast Pyrolysis Liquids, in: Developments in Thermochemical Bio mass Conversion," Blackie Academic \& Professional (Eds.), London, 1997.

[25] G. W. Huber and A. Corma, "Synergies between bio- and oil refineries for the production of fuels from biomass," Angewandte Chemie International Edition 207, pp. 7184-7201, 2007.

[26] S. R. Wang, Y. R. Wang, Q. J. Cai, X. Y. Wang, H. Jin and Z. Luo, "Multi-step separation of monophenols and pyrolytic lignins from the water-insoluble phase of bio-oil," Sep. Purif. Technol., vol. 122, pp. 248-255, 2014.

[27] Q. Zhang, J. Chang, T. J. Wang and Y. Xu, "Review of biomass pyrolysis oil properties and upgrading research," Energy Conversion and Management, vol. 48, pp. 87- 92, 2007.

[28] V. A. Bridgwater, D. Meier and D. Radlein, “An overview of past pyrolysis of biomass," Org. Geochem, vol. 30, pp. 1479-1493, 1999.

[29] W. Liu, X. Wang, C. Hu, D. Tong, L. Zhu and G. Li, "Catalytic pyrolysis of distillers dried grain white solubles: An attempt towards obtaining value-added products," International Journal of Hydrogen Energy, vol. 39, pp. 6371-6383, 2014.

[30] R. J. Nevagi, S. N. Dighe and S. N. Dighe, "Biological and medicinal significance of benzofuran," European Journal of Medical Chemistry, vol. 97, pp. 561-581, 2015.

[31] M. V. Migliorini, M. S. A. Moraes, M. E. Machado and E. B. Caramão, "Caracterização de fenóis no bio-óleo da pirólise de caroço de pêssego por GC/MS e GCxGC/TOFMS," Scientia Chromatographica, vol. 5, pp. 47-65, 2013.

[32] L. R. Almeida, A. A. Hidalgo, M. L. Veja and M. A. S. Rios,’Utilização de compostos derivados da biomassa para solução problemas industriais do setor de biocombustíveis," Estudos Tecnológicos, vol. 7, pp. 163-176, 2011.

[33] H. Yang, W. Zhao, K. Norinaga, Y. Wang, Z. Zong and X. Wei, "Separation of phenols and Ketones from bio-oil produced from ethanolysis of wheat stalk," Separation and Purification Technology, vol. 152, pp. 238-245, 2015.

[34] A. Zarrouk, H. Zarrok, R. Salghi, B. Hammouti, S, S. Al-Deyab, R. Touzani1, M. Bouachrine, I. Warad and T. B. Hadda, "A Theoretical Investigation on the Corrosion Inhibition of Copper by Quinoxaline Derivatives in Nitric Acid Solution," Int. J. Electrochem. Sci., vol. 7, pp. 6353 - 6364, 2012.

[35] J. Kim and J. Y. Jaung, "The synthesis and optical properties of meso-substituted porphyrins bearing quinoxaline derivatives," Dyes and Pigments, vol. 77, vol. 474-477, 2008.

[36] J. A. Pereira, A. M. Pessoa, M. N. D. S. Cordeiro, R. Fernandes, C. Prudêncio, J. P. Noronha and M. Vieira, "Quinoxaline, its derivates and applications: A State of the Art rewiew," European Journal of Medicinal Chemistry, vol 97, pp. 664-672, 2015.

[37] M.Vieira, C. Pinheiro, R. Fernandes, J. P. Noronha and C Prudencio, "Antimicrobial activity of quinoxaline 1,4-dioxide with 2- and 3-substituted derivatives," Microbiological Research 169: 287-293, 2014.

[38] G. W. H. Cheeseman and R. F. Cookson, "The Chemistry of Heterrocyclic Componds. Condensed Pyrazines," vol. 35, John Wiley \& Sons. Inc., 1979.

[39] J. D. Adjaye and N. N. Bakhshi, "Production of hydrocarbons by catalytic upgrading of a fast pyrolysis bio-oil. Part II: comparative catalyst performance and reaction pathways," Fuel processing technology, vol. 45, pp. 185-202, 1995. 


\section{SUPPLEMENTARY MATERIAL}

\section{SUPPLEMENTARY MATERIAL 1}

TABLE LISTED THE OTHER COMPOUNDS AND THEIR CORRESPONDING PERCENTAGE AREA IN THE BIO-OIL AND FRACTIONS (OPH, OPL, OCH AND OCL).

\begin{tabular}{|c|c|c|c|c|c|c|}
\hline \multirow{2}{*}{$\begin{array}{c}\mathbf{1}_{\mathbf{t R}} \\
(\mathrm{min})\end{array}$} & \multirow{2}{*}{$\begin{array}{l}2 \text { tR } \\
(\mathrm{s})\end{array}$} & \multirow{2}{*}{ identification } & \multicolumn{4}{|c|}{ area $\%$} \\
\hline & & & OCH & OPL & OCL & OPH \\
\hline 8,30 & 2,39 & heptane & n.d. & n.d. & 0.226 & n.d. \\
\hline 10,17 & 2,52 & octane & n.d. & 0.015 & n.d. & n.d. \\
\hline 11,50 & 2,65 & octane & 6.866 & 1.679 & 0.423 & n.d. \\
\hline 14,30 & 2,71 & nonane & 0.071 & 0.048 & 0.004 & n.d. \\
\hline 14,63 & 2,75 & nonane & 0.018 & 0.041 & n.d. & n.d. \\
\hline 16,03 & 2,84 & nonane & 1.049 & n.d. & 1.503 & n.d. \\
\hline 19,37 & 2,83 & decane & n.d. & 0.086 & n.d. & n.d. \\
\hline 19,63 & 2,86 & decane & 0.022 & 0.062 & n.d. & n.d. \\
\hline 19,77 & 2,84 & decane & 0.013 & n.d. & n.d. & n.d. \\
\hline 21,23 & 2,94 & decane & 0.599 & 0.835 & 0.458 & n.d. \\
\hline 24,57 & 2,92 & undecane & 0.022 & 0.088 & 0.018 & n.d. \\
\hline 24,83 & 2,96 & undecane & n.d. & 0.045 & n.d. & n.d. \\
\hline 26,43 & 3,01 & undecane & 0.549 & 0.881 & 0.379 & n.d. \\
\hline 27,23 & 2,92 & docecane & n.d. & 0.008 & n.d. & n.d. \\
\hline 29,37 & 3,00 & docecane & n.d. & 0.076 & n.d. & n.d. \\
\hline 31,32 & 3,06 & docecane & 0.287 & 1.037 & 0.507 & n.d. \\
\hline 32,03 & 2,98 & docecane & n.d. & 0.011 & n.d. & n.d. \\
\hline 33,23 & 3,04 & docecane & n.d. & 0.008 & n.d. & n.d. \\
\hline 33,77 & 3,04 & tridecane & 0.008 & 0.037 & 0.637 & n.d. \\
\hline 34,03 & 3,06 & tridecane & n.d. & 0.029 & 0.637 & n.d. \\
\hline 34,43 & 3,07 & tridecane & 0.006 & 0.022 & 0.637 & n.d. \\
\hline 35,90 & 3,13 & tridecane & 0.437 & 1.182 & 0.504 & n.d. \\
\hline 36,03 & 3,10 & tridecane & n.d. & 3.218 & 0.637 & n.d. \\
\hline 37,63 & 3,10 & tetradecane & n.d. & 0.002 & 0.637 & n.d. \\
\hline 38,17 & 3,09 & tetradecane & n.d. & 0.020 & 0.637 & n.d. \\
\hline 38,30 & 3,10 & tetradecane & n.d. & 0.029 & 0.637 & n.d. \\
\hline 38,97 & 3,14 & tetradecane & n.d. & 0.011 & 0.637 & n.d. \\
\hline 39,23 & 3,07 & tetradecane & n.d. & 0.008 & 0.637 & n.d. \\
\hline 40,30 & 3,18 & tetradecane & 0.421 & 0.896 & 0.510 & n.d. \\
\hline 44,30 & 3,26 & pentadecane & 0.635 & 1.250 & 0.781 & n.d. \\
\hline 44,43 & 3,23 & pentadecane & n.d. & 0.445 & 0.637 & n.d. \\
\hline 48,17 & 3,31 & hexadecane & 0.232 & 0.287 & 0.283 & n.d. \\
\hline 51,90 & 3,36 & heptadecane & n.d. & 0.272 & 0.710 & n.d. \\
\hline 55,37 & 3,42 & octadecane & n.d. & 0.025 & 0.129 & n.d. \\
\hline 58,61 & 3,49 & nonadecane & 0.021 & 0.005 & 0.029 & n.d. \\
\hline 61,77 & 3,56 & eicosane & 0.009 & n.d. & 0.637 & n.d. \\
\hline & & saturates & 11.266 & 12.659 & 13.468 & n.d. \\
\hline 8,17 & 2,45 & heptene & n.d. & 0.113 & 0.637 & n.d. \\
\hline 8,50 & 2,50 & heptene & 0.758 & n.d. & 0.201 & n.d. \\
\hline 8,97 & 2,63 & heptene & 0.334 & n.d. & 0.227 & n.d. \\
\hline 9,90 & 2,63 & heptene & 0.140 & n.d. & 0.637 & n.d. \\
\hline 11,10 & 2,71 & octene & n.d. & n.d. & 0.686 & n.d. \\
\hline 11,77 & 2,78 & octene & 1.683 & 0.401 & 0.637 & n.d. \\
\hline 12,03 & 2,79 & octene & n.d. & 0.212 & 0.076 & n.d. \\
\hline 13,50 & 2,80 & octene & 0.087 & 0.077 & 0.637 & n.d. \\
\hline 13,90 & 2,81 & octene & 0.082 & 0.049 & 0.637 & n.d. \\
\hline
\end{tabular}




\begin{tabular}{|c|c|c|c|c|c|c|}
\hline 15,63 & 2,97 & octene & 1.206 & 2.267 & 0.637 & n.d. \\
\hline 16,03 & 2,99 & nonene & 0.169 & n.d. & 0.637 & n.d. \\
\hline 16,30 & 2,96 & nonene & 0.386 & 0.444 & 0.083 & n.d. \\
\hline 16,43 & 2,94 & nonene & n.d. & 0.136 & 0.637 & n.d. \\
\hline 16,70 & 2,99 & nonene & 0.247 & 0.290 & 0.043 & n.d. \\
\hline 18,43 & 2,96 & nonene & 0.037 & 0.039 & 0.637 & n.d. \\
\hline 18,83 & 2,96 & decene & 0.056 & 0.038 & 0.637 & n.d. \\
\hline 20,43 & 3,04 & decene & n.d. & 0.373 & 0.637 & n.d. \\
\hline 20,83 & 3,05 & decene & 1.290 & n.d. & 1.022 & n.d. \\
\hline 21,10 & 3,06 & decene & n.d. & 0.422 & 0.067 & n.d. \\
\hline 21,50 & 3,08 & decene & 0.346 & 0.591 & 0.122 & n.d. \\
\hline 21,90 & 3,11 & decene & 0.130 & 0.651 & 0.081 & n.d. \\
\hline 23,77 & 3,05 & decene & 0.065 & 0.184 & 0.637 & n.d. \\
\hline 24,17 & 3,04 & undecene & 0.019 & 0.064 & 0.637 & n.d. \\
\hline 24,43 & 3,08 & undecene & n.d. & 0.040 & 0.637 & n.d. \\
\hline 25,63 & 3,11 & undecene & n.d. & n.d. & 0.036 & n.d. \\
\hline 26,30 & 3,13 & undecene & 0.567 & 1.195 & 0.637 & n.d. \\
\hline 26,70 & 3,15 & undecene & 0.481 & 0.855 & 0.320 & n.d. \\
\hline 27,10 & 3,17 & undecene & n.d. & n.d. & 0.165 & n.d. \\
\hline 28,70 & 3,10 & undecene & 0.041 & 0.167 & 0.637 & n.d. \\
\hline 29,50 & 3,14 & dodecene & n.d. & 0.045 & 0.637 & n.d. \\
\hline 30,57 & 3,19 & dodecene & n.d. & 0.687 & 0.637 & n.d. \\
\hline 30,83 & 3,20 & dodecene & n.d. & 0.912 & 0.637 & n.d. \\
\hline 30,97 & 3,21 & dodecene & n.d. & 1.679 & 0.995 & n.d. \\
\hline 31,54 & 3,21 & dodecene & 0.169 & 0.705 & 0.128 & n.d. \\
\hline 32,03 & 3,23 & dodecene & 0.070 & 0.361 & 0.032 & n.d. \\
\hline 34,57 & 3,29 & tridecene & 0.032 & n.d. & 0.637 & n.d. \\
\hline 35,50 & 3,24 & tridecene & 0.739 & n.d. & 0.672 & n.d. \\
\hline 36,17 & 3,26 & tridecene & n.d. & 0.286 & 0.060 & n.d. \\
\hline 36,57 & 3,29 & tridecene & 0.030 & 0.239 & 0.024 & n.d. \\
\hline 37,77 & 3,22 & tridecene & n.d. & 0.046 & 0.637 & n.d. \\
\hline 38,30 & 3,13 & tetradecene & 0.019 & 0.022 & 0.637 & n.d. \\
\hline 38,70 & 3,36 & tetradecene & n.d. & n.d. & 0.025 & n.d. \\
\hline 39,90 & 3,31 & tetradecene & 0.763 & n.d. & 0.943 & n.d. \\
\hline 40,43 & 3,32 & tetradecene & 0.040 & 0.196 & 0.045 & n.d. \\
\hline 40,83 & 3,36 & tetradecene & n.d. & n.d. & 0.018 & n.d. \\
\hline 42,03 & 3,27 & tetradecene & n.d. & 0.027 & 0.637 & n.d. \\
\hline 42,83 & 3,41 & tetradecene & 0.027 & n.d. & 0.042 & n.d. \\
\hline 43,77 & 3,38 & tetradecene & n.d. & 0.465 & 0.262 & n.d. \\
\hline 44,03 & 3,36 & pentadecene & n.d. & n.d. & 0.817 & n.d. \\
\hline 44,57 & 3,38 & pentadecene & n.d. & 0.188 & 0.637 & n.d. \\
\hline 44,97 & 3,42 & pentadecene & n.d. & 0.096 & 0.024 & n.d. \\
\hline 45,90 & 3,33 & pentadecene & n.d. & 0.015 & 0.637 & n.d. \\
\hline 46,83 & 3,48 & hexadecene & n.d. & 0.051 & 0.020 & n.d. \\
\hline 47,63 & 3,44 & hexadecene & 0.122 & 0.155 & 0.141 & n.d. \\
\hline 47,90 & 3,43 & hexadecene & 0.510 & 0.511 & 0.637 & n.d. \\
\hline 48,43 & 3,43 & hexadecene & n.d. & 0.053 & 0.637 & n.d. \\
\hline 48,83 & 3,47 & hexadecene & n.d. & 0.029 & 0.637 & n.d. \\
\hline 50,57 & 3,54 & hexadecene & n.d. & 0.063 & 0.637 & n.d. \\
\hline 51,23 & 3,51 & heptadecene & 0.122 & n.d. & 0.185 & n.d. \\
\hline 51,63 & 3,48 & heptadecene & 0.377 & 0.280 & 0.637 & n.d. \\
\hline 52,03 & 3,50 & octadecene & 0.021 & n.d. & 0.637 & n.d. \\
\hline
\end{tabular}




\begin{tabular}{|c|c|c|c|c|c|c|}
\hline 54,70 & 3,57 & octadecene & n.d. & n.d. & 0.031 & n.d. \\
\hline 55,10 & 3,54 & octadecene & 0.065 & 0.024 & 0.637 & n.d. \\
\hline 55,50 & 3,56 & octadecene & n.d. & n.d. & 0.017 & n.d. \\
\hline 58,43 & 3,60 & nonadecene & 0.034 & n.d. & 0.637 & n.d. \\
\hline 58,43 & 3,60 & nonadecene & 0.034 & n.d. & 0.035 & n.d. \\
\hline 61,63 & 3,67 & eicosene & 0.016 & n.d. & 0.030 & n.d. \\
\hline 64,57 & 3,75 & heneicosene & n.d. & n.d. & 0.018 & n.d. \\
\hline & & olefins & 11.310 & 15.745 & 28.707 & n.d. \\
\hline 7,77 & 2,52 & Heptadiene & n.d. & n.d. & 0.051 & n.d. \\
\hline 8,70 & 2,64 & Heptadiene & 2.370 & n.d. & 0.637 & n.d. \\
\hline 10,17 & 2,91 & Octadiene & 0.466 & n.d. & 0.637 & n.d. \\
\hline 10,70 & 3,00 & Octadiene & 0.587 & n.d. & 0.637 & n.d. \\
\hline 10,97 & 2,83 & Octadiene & 0.062 & n.d. & 0.637 & n.d. \\
\hline 11,37 & 2,83 & Octadiene & n.d. & n.d. & 0.099 & n.d. \\
\hline 11,63 & 2,93 & Octadiene & 0.807 & n.d. & 0.637 & n.d. \\
\hline 12,57 & 2,97 & Octadiene & n.d. & n.d. & 0.083 & n.d. \\
\hline 13,77 & 3,09 & Octadiene & n.d. & n.d. & 0.119 & n.d. \\
\hline 13,37 & 3,26 & Octadiene & n.d. & 0.330 & 0.637 & n.d. \\
\hline 14,17 & 3,17 & Octadiene & n.d. & 0.282 & 0.637 & n.d. \\
\hline 14,70 & 3,10 & Octadiene & 0.560 & n.d. & 0.059 & n.d. \\
\hline 15,90 & 3,09 & Nonadiene & n.d. & 0.122 & 0.637 & n.d. \\
\hline 16,03 & 3,22 & Nonadiene & n.d. & 0.257 & 0.637 & n.d. \\
\hline 16,37 & 3,18 & Nonadiene & 0.250 & n.d. & 0.031 & n.d. \\
\hline 18,57 & 3,29 & Decadiene & 0.076 & n.d. & 0.052 & n.d. \\
\hline 19,50 & 3,25 & Decadiene & n.d. & 0.332 & 0.637 & n.d. \\
\hline 19,90 & 3,24 & Decadiene & n.d. & n.d. & 0.087 & n.d. \\
\hline 20,90 & 3,20 & Decadiene & 0.352 & n.d. & 0.173 & n.d. \\
\hline 22,03 & 3,36 & Decadiene & n.d. & n.d. & 0.097 & n.d. \\
\hline 25,10 & 3,36 & Undecadiene & 0.158 & 0.413 & 0.071 & n.d. \\
\hline 25,50 & 3,25 & Undecadiene & 0.316 & n.d. & 0.087 & n.d. \\
\hline 25,77 & 3,26 & Undecadiene & 0.636 & n.d. & n.d. & n.d. \\
\hline 26,43 & 3,45 & Undecadiene & 0.115 & n.d. & n.d. & n.d. \\
\hline 27,10 & 3,36 & Undecadiene, & 0.134 & n.d. & n.d. & n.d. \\
\hline 27,63 & 3,38 & Undecadiene, & n.d. & n.d. & 0.185 & n.d. \\
\hline 30,17 & 3,41 & Dodecadiene & 0.043 & n.d. & n.d. & n.d. \\
\hline 30,43 & 3,32 & Dodecadiene & n.d. & 0.403 & n.d. & n.d. \\
\hline 30,57 & 3,30 & Dodecadiene & 0.299 & n.d. & 0.125 & n.d. \\
\hline 31,10 & 3,36 & Dodecadiene & n.d. & 1.289 & n.d. & n.d. \\
\hline 32,57 & 3,41 & Dodecadiene & 0.062 & n.d. & n.d. & n.d. \\
\hline 33,10 & 3,51 & Dodecadiene & 0.422 & 0.925 & n.d. & n.d. \\
\hline 33,37 & 3,50 & Dodecadiene & n.d. & n.d. & 0.040 & n.d. \\
\hline 33,90 & 3,51 & Dodecadiene & n.d. & 0.321 & n.d. & n.d. \\
\hline 34,17 & 3,53 & Tridecadiene & n.d. & n.d. & 0.044 & n.d. \\
\hline 34,83 & 3,46 & Tridecadiene & n.d. & 0.122 & n.d. & n.d. \\
\hline 35,10 & 3,38 & Tridecadiene & n.d. & 0.285 & n.d. & n.d. \\
\hline 35,37 & 3,36 & Tridecadiene & 0.314 & n.d. & n.d. & n.d. \\
\hline 35,77 & 3,41 & Tridecadiene & 0.047 & n.d. & n.d. & n.d. \\
\hline 37,10 & 3,46 & Tridecadiene & 0.027 & n.d. & n.d. & n.d. \\
\hline 38,43 & 3,55 & Tetradecadiene & n.d. & 0.171 & n.d. & n.d. \\
\hline 38,57 & 3,59 & Tetradecadiene & n.d. & 0.106 & n.d. & n.d. \\
\hline 39,37 & 3,45 & Tetradecadiene & 0.101 & 0.208 & 0.089 & n.d. \\
\hline 39,63 & 3,42 & Tetradecadiene & 0.111 & n.d. & 0.102 & n.d. \\
\hline
\end{tabular}




\begin{tabular}{|c|c|c|c|c|c|c|}
\hline 43,37 & 3,53 & Tetradecadiene & n.d. & 0.062 & n.d. & n.d. \\
\hline 43,50 & 3,50 & Pentadecadiene & n.d. & 0.082 & 0.078 & n.d. \\
\hline 44,57 & 3,70 & Pentadecadiene & n.d. & 0.142 & n.d. & n.d. \\
\hline 45,50 & 3,68 & Pentadecadiene & n.d. & 0.063 & n.d. & n.d. \\
\hline 46,57 & 3,61 & Hexadecadiene & n.d. & n.d. & 0.066 & n.d. \\
\hline 47,37 & 3,57 & Hexadecadiene & 0.412 & 0.216 & 0.530 & n.d. \\
\hline 50,83 & 3,64 & Heptadecadiene & n.d. & 0.151 & n.d. & n.d. \\
\hline 50,97 & 3,64 & Heptadecadiene & n.d. & n.d. & 0.417 & n.d. \\
\hline 51,10 & 3,62 & Heptadecadiene & n.d. & 0.159 & n.d. & n.d. \\
\hline 54,57 & 3,73 & Octadecadiene & n.d. & n.d. & 0.026 & n.d. \\
\hline & & diolefins & 8.728 & 6.439 & 9.080 & n.d. \\
\hline 7,63 & 2,84 & Benzene & 2.085 & n.d. & n.d. & n.d. \\
\hline 10,67 & 3,42 & Toluene & 6.257 & 1.031 & 0.031 & 0.221 \\
\hline 14,37 & 3,79 & Benzene, C2 & n.d. & 1.148 & 1.738 & n.d. \\
\hline 15,10 & 3,78 & Benzene, $\mathrm{C} 2$ & 0.374 & n.d. & n.d. & n.d. \\
\hline 15,63 & 4,00 & Benzene, $\mathrm{C} 2$ & n.d. & n.d. & 2.005 & 0.025 \\
\hline 15,63 & 4,23 & Benzene, $\mathrm{C} 2$ & n.d. & n.d. & 2.539 & n.d. \\
\hline 16,83 & 4,15 & Benzene, C3 & n.d. & 0.016 & n.d. & n.d. \\
\hline 17,23 & 3,90 & Benzene, C3 & n.d. & 0.118 & 0.106 & n.d. \\
\hline 18,83 & 3,97 & Benzene, $\mathrm{C} 3$ & n.d. & 1.047 & 0.653 & n.d. \\
\hline 19,23 & 4,03 & Benzene, C3 & 1.322 & n.d. & 1.035 & n.d. \\
\hline 20,03 & 4,21 & Benzene, C3 & 0.310 & n.d. & n.d. & n.d. \\
\hline 20,17 & 4,19 & Benzene, C3 & 1.670 & n.d. & 1.053 & n.d. \\
\hline 20,17 & 4,34 & Benzene, C3 & 0.080 & n.d. & n.d. & n.d. \\
\hline 20,83 & 4,19 & Benzene, C3 & 0.974 & 1.042 & 0.662 & n.d. \\
\hline 22,30 & 4,42 & Benzene, C3 & 0.588 & n.d. & 0.119 & n.d. \\
\hline 22,43 & 4,39 & Benzene, C3 & n.d. & 0.538 & n.d. & n.d. \\
\hline 21,63 & 3,91 & Benzene, C4 & n.d. & n.d. & 0.036 & n.d. \\
\hline 22,43 & 4,01 & Benzene, C4 & n.d. & 0.155 & 0.075 & n.d. \\
\hline 23,23 & 4,14 & Benzene, C4 & 0.115 & 0.101 & 0.067 & n.d. \\
\hline 23,90 & 4,06 & Benzene, C4 & 0.951 & 1.034 & 0.540 & n.d. \\
\hline 24,17 & 4,08 & Benzene, C4 & n.d. & n.d. & 0.653 & n.d. \\
\hline 24,30 & 4,11 & Benzene, C4 & n.d. & 1.704 & 0.861 & n.d. \\
\hline 24,43 & 4,27 & Benzene, C4 & 0.298 & 0.439 & 0.173 & n.d. \\
\hline 24,70 & 4,20 & Benzene, C4 & n.d. & 1.195 & 0.479 & n.d. \\
\hline 25,23 & 4,22 & Benzene, C4 & n.d. & 0.523 & 0.240 & n.d. \\
\hline 25,63 & 4,27 & Benzene, C4 & n.d. & 0.573 & 0.235 & n.d. \\
\hline 26,70 & 4,49 & Benzene, C4 & n.d. & 0.218 & 0.198 & n.d. \\
\hline 26,83 & 4,08 & Benzene, C4 & 0.022 & n.d. & n.d. & n.d. \\
\hline 27,37 & 4,43 & Benzene, C4 & 0.224 & n.d. & 0.045 & n.d. \\
\hline 28,97 & 4,47 & Benzene, C4 & 0.124 & 0.336 & 0.014 & n.d. \\
\hline 26,57 & 4,04 & Benzene, C5 & n.d. & n.d. & 0.025 & n.d. \\
\hline 26,70 & 4,03 & Benzene, C5 & n.d. & 0.060 & n.d. & n.d. \\
\hline 27,23 & 4,13 & Benzene, C5 & n.d. & 0.159 & 0.052 & n.d. \\
\hline 28,30 & 4,09 & Benzene, C5 & n.d. & 0.282 & 0.120 & n.d. \\
\hline 28,70 & 4,18 & Benzene, C5 & n.d. & n.d. & 0.225 & n.d. \\
\hline 28,97 & 4,13 & Benzene, C5 & n.d. & n.d. & 0.120 & n.d. \\
\hline 29,23 & 4,13 & Benzene, C5 & n.d. & n.d. & 0.737 & n.d. \\
\hline 29,37 & 4,19 & Benzene, C5 & n.d. & n.d. & 0.034 & n.d. \\
\hline 29,50 & 4,08 & Benzene, C5 & n.d. & 0.186 & n.d. & n.d. \\
\hline 29,50 & 4,26 & Benzene, C5 & n.d. & 0.163 & 0.206 & n.d. \\
\hline 29,77 & 4,26 & Benzene, C5 & 0.094 & 1.315 & 0.316 & n.d. \\
\hline
\end{tabular}




\begin{tabular}{|c|c|c|c|c|c|c|}
\hline 29,77 & 4,43 & Benzene, C5 & 0.068 & 0.058 & n.d. & n.d. \\
\hline 30,17 & 4,25 & Benzene, C5 & n.d. & n.d. & 0.026 & n.d. \\
\hline 30,97 & 4,50 & Benzene, C5 & n.d. & 0.250 & 0.015 & n.d. \\
\hline 31,23 & 4,39 & Benzene, C5 & n.d. & 0.059 & n.d. & n.d. \\
\hline 31,37 & 4,44 & Benzene, C5 & n.d. & 0.041 & n.d. & n.d. \\
\hline 31,63 & 4,14 & Benzene, C6 & n.d. & 0.046 & n.d. & n.d. \\
\hline 32,43 & 4,17 & Benzene, C6 & n.d. & n.d. & 0.044 & n.d. \\
\hline 33,37 & 4,36 & Benzene, C6 & n.d. & 0.053 & 0.067 & n.d. \\
\hline 33,63 & 4,21 & Benzene, C6 & 0.036 & n.d. & 0.034 & n.d. \\
\hline 33,63 & 4,25 & Benzene, C6 & n.d. & n.d. & 0.034 & n.d. \\
\hline 33,77 & 4,16 & Benzene, C6 & n.d. & n.d. & 0.090 & n.d. \\
\hline 34,03 & 4,19 & Benzene, C6 & n.d. & 0.388 & 0.418 & n.d. \\
\hline 34,17 & 4,16 & Benzene, C6 & 0.516 & 0.520 & n.d. & n.d. \\
\hline 34,43 & 4,28 & Benzene, C6 & n.d. & 0.850 & n.d. & n.d. \\
\hline 34,83 & 4,33 & Benzene, C6 & n.d. & n.d. & 0.026 & n.d. \\
\hline 34,97 & 4,30 & Benzene, C6 & n.d. & 0.073 & n.d. & n.d. \\
\hline 38,57 & 4,21 & Benzene, C7 & n.d. & 0.357 & n.d. & n.d. \\
\hline 38,70 & 4,21 & Benzene, C7 & n.d. & 0.256 & n.d. & n.d. \\
\hline 39,23 & 4,38 & Benzene, C7 & n.d. & 0.056 & n.d. & n.d. \\
\hline 43,10 & 4,24 & Benzene, C8 & n.d. & 0.135 & 0.064 & n.d. \\
\hline 44,83 & 4,23 & Benzene, C8 & n.d. & n.d. & 0.039 & n.d. \\
\hline 46,57 & 4,31 & Benzene, C9 & 0.021 & n.d. & 0.036 & n.d. \\
\hline 47,10 & 4,31 & Benzene, C9 & 0.057 & 0.032 & 0.067 & n.d. \\
\hline 50,97 & 4,38 & Benzene, $\mathrm{C} 10$ & n.d. & 0.026 & 0.042 & n.d. \\
\hline 51,90 & 4,33 & Benzene, C11 & n.d. & n.d. & 0.025 & n.d. \\
\hline \multirow[t]{2}{*}{54,83} & 4,49 & Benzene, $\mathrm{C} 11$ & n.d. & n.d. & 0.060 & n.d. \\
\hline & & alkyl benzenes & 16.186 & 16.582 & 16.482 & 0.246 \\
\hline 22,97 & 4,79 & Indane & n.d. & 1.025 & 0.471 & n.d. \\
\hline 27,10 & 4,79 & Indane, methyl & n.d. & n.d. & 0.080 & n.d. \\
\hline 28,30 & 4,81 & Indane, methyl & 0.299 & n.d. & 0.171 & n.d. \\
\hline 28,83 & 4,74 & Indane, methyl & 0.373 & 0.161 & 0.271 & n.d. \\
\hline 30,70 & 4,64 & Indane, $\mathrm{C} 2$ & n.d. & 0.365 & 0.141 & n.d. \\
\hline 30,97 & 4,64 & Indane, $\mathrm{C} 2$ & n.d. & 0.433 & 0.146 & n.d. \\
\hline 31,23 & 4,75 & Indane, $\mathrm{C} 2$ & n.d. & 0.204 & 0.132 & n.d. \\
\hline 31,90 & 4,65 & Indane, $\mathrm{C} 2$ & 0.128 & n.d. & 0.074 & n.d. \\
\hline 32,97 & 4,93 & Indane, $\mathrm{C} 2$ & n.d. & 0.179 & 0.110 & n.d. \\
\hline 34,30 & 4,99 & Indane, $\mathrm{C} 2$ & n.d. & 0.087 & n.d. & n.d. \\
\hline 35,77 & 4,71 & Indane, $\mathrm{C} 3$ & n.d. & n.d. & 0.052 & n.d. \\
\hline \multirow[t]{2}{*}{37,10} & 4,87 & Indane, $\mathrm{C} 3$ & n.d. & 0.020 & 0.011 & n.d. \\
\hline & & alkyl indanes & 0.799 & 2.473 & 1.658 & n.d. \\
\hline 23,50 & 5,13 & indene & n.d. & 2.459 & 1.428 & n.d. \\
\hline 28,83 & 5,18 & Indene, methyl & 1.340 & 1.242 & 1.260 & n.d. \\
\hline 33,90 & 5,14 & Indene, $\mathrm{C} 2$ & 1.084 & n.d. & n.d. & n.d. \\
\hline 34,21 & 5,23 & Indene, $\mathrm{C} 2$ & 0.281 & 0.520 & 0.397 & n.d. \\
\hline 34,57 & 5,28 & Indene, $\mathrm{C} 2$ & n.d. & 0.348 & 0.634 & n.d. \\
\hline 34,77 & 5,30 & Indene, $\mathrm{C} 2$ & n.d. & 0.146 & 0.484 & n.d. \\
\hline 35,63 & 5,53 & Indene, $\mathrm{C} 2$ & 0.442 & 0.147 & 0.251 & n.d. \\
\hline 35,90 & 5,42 & Indene, $\mathrm{C} 2$ & n.d. & 0.016 & 0.075 & n.d. \\
\hline 37,77 & 5,20 & Indene, C3 & 0.052 & 0.191 & 0.067 & n.d. \\
\hline 38,17 & 5,27 & Indene, C3 & n.d. & 0.138 & 0.097 & n.d. \\
\hline 38,43 & 5,17 & Indene, $\mathrm{C} 3$ & n.d. & 0.115 & 0.071 & n.d. \\
\hline 38,83 & 5,51 & Indene, $\mathrm{C} 3$ & 0.085 & 0.034 & 0.206 & n.d. \\
\hline
\end{tabular}




\begin{tabular}{|c|c|c|c|c|c|c|}
\hline 39,23 & 5,26 & Indene, C3 & 0.836 & 0.130 & n.d. & n.d. \\
\hline 39,50 & 5,34 & Indene, $\mathrm{C} 3$ & n.d. & 0.059 & n.d. & n.d. \\
\hline \multirow{2}{*}{40,17} & 5,49 & Indene, $\mathrm{C} 3$ & n.d. & 0.060 & 0.076 & n.d. \\
\hline & & alkyl indenes & 4.121 & 5.605 & 5.045 & n.d. \\
\hline 27,77 & 4,65 & Styrene, C2 & n.d. & 0.072 & 0.044 & n.d. \\
\hline 27,90 & 4,56 & Styrene, C2 & n.d. & n.d. & 0.110 & n.d. \\
\hline 30,03 & 4,44 & Styrene, C3 & n.d. & 0.147 & 0.090 & n.d. \\
\hline 30,17 & 4,49 & Styrene, C3 & 0.072 & 0.258 & 0.038 & n.d. \\
\hline 33,63 & 4,91 & Styrene, C4 & 0.067 & 0.111 & n.d. & n.d. \\
\hline 34,88 & 4,85 & Styrene, C4 & 0.084 & 0.236 & 0.308 & n.d. \\
\hline 35,10 & 4,90 & Styrene, C5 & 0.190 & n.d. & n.d. & n.d. \\
\hline \multirow[t]{2}{*}{36,83} & 4,89 & Styrene, C6 & n.d. & 0.034 & n.d. & n.d. \\
\hline & & alkyl styrenes & 0.413 & 0.858 & 0.590 & n.d. \\
\hline 21,90 & 4,13 & Benzene, propenyl & n.d. & n.d. & 0.134 & n.d. \\
\hline 23,63 & 4,28 & Benzene, methylpropenyl & 0.157 & 0.087 & 0.274 & n.d. \\
\hline 24,43 & 4,32 & Benzene, methylpropenyl & n.d. & n.d. & 0.134 & n.d. \\
\hline 25,97 & 4,34 & Benzene, methylpropenyl & n.d. & 0.082 & 0.217 & n.d. \\
\hline 28,97 & 4,44 & Benzene, C2-propenyl & n.d. & 0.507 & n.d. & n.d. \\
\hline 30,57 & 4,49 & Benzene, C2-propenyl & 0.277 & 0.202 & n.d. & n.d. \\
\hline 31,63 & 4,62 & Benzene, C2-propenyl & n.d. & 0.091 & n.d. & n.d. \\
\hline \multirow[t]{2}{*}{32,43} & 4,54 & Benzene, C2-propenyl & n.d. & 0.144 & n.d. & n.d. \\
\hline & & propenyl benzenes & 0.434 & 1.114 & 0.760 & n.d. \\
\hline 30,30 & 4,93 & Benzene, methyl butenyl & n.d. & 0.305 & n.d. & n.d. \\
\hline 32,43 & 5,10 & Benzene, C2- butenyl- & n.d. & 0.133 & n.d. & n.d. \\
\hline 33,37 & 5,25 & Benzene, C2- butenyl- & 0.360 & 0.355 & 0.281 & n.d. \\
\hline 34,17 & 5,03 & Benzene, C2- butenyl- & 0.618 & 0.034 & n.d. & n.d. \\
\hline 37,37 & 5,17 & Benzene, C3- butenyl- & n.d. & 0.030 & n.d. & n.d. \\
\hline \multirow[t]{2}{*}{38,30} & 5,20 & Benzene, C3-butenyl- & 0.048 & 0.138 & n.d. & n.d. \\
\hline & & butenyl benzenes & 1.027 & 0.995 & 0.281 & n.d. \\
\hline 29,10 & 5,26 & Naphthalene, dihydro- & n.d. & 1.814 & n.d. & n.d. \\
\hline 29,50 & 5,51 & Naphthalene, dihydro & n.d. & n.d. & 0.531 & n.d. \\
\hline 32,03 & 5,31 & Naphthalene, dihydro methyl- & n.d. & 0.079 & n.d. & n.d. \\
\hline 33,10 & 5,33 & Naphthalene, dihydro methyl- & 0.139 & n.d. & n.d. & n.d. \\
\hline 29,37 & 5,19 & Naphthalene, tetrahydro & 0.744 & 0.658 & 0.482 & n.d. \\
\hline 32,03 & 4,96 & Naphthalene, tetrahydro methyl- & n.d. & 0.084 & n.d. & n.d. \\
\hline \multirow[t]{2}{*}{35,63} & 5,40 & Naphthalene, tetrahydro methyl & 0.146 & 0.189 & 0.179 & n.d. \\
\hline & & di and tetrahydronaphthalenes & 1.029 & 2.824 & 1.192 & n.d. \\
\hline 29,23 & 5,66 & Naphthalene & n.d. & n.d. & 0.207 & n.d. \\
\hline 34,43 & 5,66 & Naphthalene, methyl & n.d. & n.d. & 0.171 & n.d. \\
\hline 35,77 & 5,88 & Naphthalene, methyl- & n.d. & 0.770 & n.d. & n.d. \\
\hline 36,43 & 6,17 & Naphthalene, methyl & n.d. & 0.590 & 1.097 & n.d. \\
\hline 40,03 & 5,88 & Naphthalene, C2 & n.d. & n.d. & 0.354 & n.d. \\
\hline 40,17 & 5,82 & Naphthalene, C2 & n.d. & 0.135 & n.d. & n.d. \\
\hline 40,17 & 6,12 & Naphthalene, C2 & 0.231 & 0.053 & 0.155 & n.d. \\
\hline 40,57 & 5,83 & Naphthalene, C2 & n.d. & 0.077 & n.d. & n.d. \\
\hline 41,10 & 6,06 & Naphthalene, $\mathrm{C} 2$ & n.d. & n.d. & 0.413 & n.d. \\
\hline 41,23 & 6,04 & Naphthalene, C2 & n.d. & 0.136 & n.d. & n.d. \\
\hline 41,90 & 6,17 & Naphthalene, C2 & n.d. & n.d. & 0.138 & n.d. \\
\hline 42,57 & 6,40 & Naphthalene, C2 & n.d. & n.d. & 0.117 & n.d. \\
\hline 42,70 & 6,35 & Naphthalene, $\mathrm{C} 2$ & n.d. & 0.028 & n.d. & n.d. \\
\hline 44,03 & 5,78 & Naphthalene, C3 & n.d. & n.d. & 0.073 & n.d. \\
\hline 44,30 & 5,91 & Naphthalene, C3 & n.d. & n.d. & 0.013 & n.d. \\
\hline
\end{tabular}




\begin{tabular}{|c|c|c|c|c|c|c|}
\hline 44,83 & 5,92 & Naphthalene, C3 & n.d. & n.d. & 0.061 & n.d. \\
\hline 46,97 & 6,22 & Naphthalene, C3 & n.d. & n.d. & 0.034 & n.d. \\
\hline \multirow{2}{*}{48,30} & 5,74 & Naphthalene, C4 & n.d. & n.d. & 0.009 & n.d. \\
\hline & & alkyl naphthalenes & 0.231 & 1.790 & 2.843 & n.d. \\
\hline 41,63 & 6,30 & Biphenyl & n.d. & n.d. & 0.413 & n.d. \\
\hline 43,90 & 6,08 & Biphenyl, methyl & n.d. & n.d. & 0.047 & n.d. \\
\hline \multirow[t]{2}{*}{46,17} & 6,23 & Biphenyl, methyl & n.d. & n.d. & 0.099 & n.d. \\
\hline & & alkyl biphenyls & n.d. & n.d. & 0.560 & n.d. \\
\hline 42,37 & 7,17 & Biphenylene & 0.523 & n.d. & 0.285 & n.d. \\
\hline 43,77 & 7,01 & Acenaphthene & 0.129 & n.d. & 0.095 & n.d. \\
\hline 48,57 & 7,41 & Fluorene & n.d. & n.d. & 0.018 & n.d. \\
\hline 52,17 & 7,25 & Fluorene, methyl & n.d. & n.d. & 0.043 & n.d. \\
\hline 52,57 & 7,43 & Fluorene, methyl & n.d. & n.d. & 0.055 & n.d. \\
\hline 53,37 & 7,36 & Fluorene, methyl & n.d. & n.d. & 0.019 & n.d. \\
\hline 49,37 & 7,49 & Benzonaphthene & n.d. & n.d. & 0.027 & n.d. \\
\hline 54,97 & 8,41 & Phenanthrene & n.d. & n.d. & 0.040 & n.d. \\
\hline \multirow[t]{2}{*}{58,83} & 8,13 & Phenanthrene, methyl & n.d. & n.d. & 0.015 & n.d. \\
\hline & & polyaromatics & 0.652 & n.d. & 0.597 & n.d. \\
\hline 8,43 & 2,69 & Cyclopentadiene, methyl & 2.130 & n.d. & n.d. & n.d. \\
\hline 10,30 & 3,18 & Cyclopentadiene, $\mathrm{C} 2$ & 2.620 & n.d. & n.d. & n.d. \\
\hline 14,03 & 3,39 & Cyclopentadiene, $\mathrm{C} 3$ & n.d. & 0.709 & n.d. & n.d. \\
\hline 16,43 & 3,81 & Cyclopentadiene, $\mathrm{C} 3$ & 1.259 & n.d. & n.d. & n.d. \\
\hline 18,57 & 4,75 & Cyclopentadiene, $\mathrm{C} 4$ & n.d. & n.d. & n.d. & 0.587 \\
\hline 19,23 & 3,67 & Cyclopentadiene, $\mathrm{C} 4$ & 0.102 & n.d. & n.d. & n.d. \\
\hline 21,90 & 3,82 & Cyclopentadiene, $\mathrm{C} 4$ & n.d. & 0.087 & n.d. & n.d. \\
\hline \multirow[t]{2}{*}{24,97} & 4,97 & Cyclopentadiene, C5 & n.d. & n.d. & n.d. & 2.157 \\
\hline & & cyclopentadienes & 6.111 & 0.796 & n.d. & 2.744 \\
\hline 9,90 & 2,81 & Cyclopentene, $\mathrm{C} 2$ & n.d. & n.d. & 0.156 & n.d. \\
\hline 12,83 & 3,01 & Cyclopentene, $\mathrm{C} 3$ & n.d. & 0.288 & 0.215 & n.d. \\
\hline 13,10 & 3,03 & Cyclopentene, $\mathrm{C} 3$ & n.d. & 0.095 & 0.022 & n.d. \\
\hline 13,50 & 3,08 & Cyclopentene, $\mathrm{C} 3$ & n.d. & 0.342 & 0.058 & n.d. \\
\hline 14,97 & 3,08 & Cyclopentene, C3 & 0.382 & n.d. & n.d. & n.d. \\
\hline 18,03 & 3,31 & Cyclopentene, C4 & n.d. & 0.134 & n.d. & n.d. \\
\hline 18,43 & 3,29 & Cyclopentene, C4 & n.d. & n.d. & 0.225 & n.d. \\
\hline 23,63 & 3,42 & Cyclopentene, C5 & n.d. & 0.676 & 0.227 & n.d. \\
\hline 27,63 & 3,44 & Cyclopentene, C6 & n.d. & 1.192 & n.d. & n.d. \\
\hline 28,83 & 3,48 & Cyclopentene, C6 & 0.313 & n.d. & 0.262 & n.d. \\
\hline 33,63 & 3,55 & Cyclopentene, C7 & n.d. & 0.556 & 0.074 & n.d. \\
\hline 38,17 & 3,61 & Cyclopentene, C8 & 0.069 & 0.330 & 0.145 & n.d. \\
\hline 38,30 & 3,58 & Cyclopentene, C8 & 0.106 & n.d. & n.d. & n.d. \\
\hline 38,70 & 3,76 & Cyclopentene, C8 & 0.054 & n.d. & n.d. & n.d. \\
\hline 42,57 & 3,67 & Cyclopentene, C9 & 0.139 & 0.343 & 0.171 & n.d. \\
\hline 45,77 & 3,68 & Cyclopentene, C10 & n.d. & n.d. & 0.020 & n.d. \\
\hline 46,57 & 3,73 & Cyclopentene, C10 & n.d. & 0.241 & n.d. & n.d. \\
\hline 50,30 & 3,72 & Cyclopentene, C11 & n.d. & 0.048 & n.d. & n.d. \\
\hline \multirow[t]{2}{*}{54,03} & 3,89 & Cyclopentene, C12 & n.d. & n.d. & 0.010 & n.d. \\
\hline & & cyclopentenes & 1.065 & 4.245 & 1.582 & n.d. \\
\hline 9,23 & 2,65 & Cyclopentane, $\mathrm{C} 2$ & n.d. & 0.022 & n.d. & n.d. \\
\hline 17,23 & 3,11 & Cyclopentane, C4 & n.d. & 0.303 & 0.078 & n.d. \\
\hline 17,63 & 3,13 & Cyclopentane, C4 & n.d. & 0.457 & n.d. & n.d. \\
\hline 22,83 & 3,29 & Cyclopentane, C5 & n.d. & n.d. & 0.085 & n.d. \\
\hline 23,10 & 3,24 & Cyclopentane, C6 & 0.108 & 0.248 & 0.031 & n.d. \\
\hline
\end{tabular}




\begin{tabular}{|c|c|c|c|c|c|c|}
\hline 25,10 & 3,19 & Cyclopentane, C7 & n.d. & 0.084 & n.d. & n.d. \\
\hline 25,90 & 3,12 & Cyclopentane, C8 & n.d. & n.d. & 1.082 & n.d. \\
\hline 28,30 & 3,33 & Cyclopentane, C6 & 0.087 & 0.293 & 0.059 & n.d. \\
\hline 29,90 & 3,25 & Cyclopentane, C6 & n.d. & 0.209 & n.d. & n.d. \\
\hline 33,23 & 3,39 & Cyclopentane, $\mathrm{C} 7$ & 0.069 & n.d. & n.d. & n.d. \\
\hline 42,17 & 3,60 & Cyclopentane, C9 & n.d. & n.d. & 0.160 & n.d. \\
\hline \multirow[t]{2}{*}{46,30} & 3,68 & Cyclopentane, $\mathrm{C} 10$ & n.d. & n.d. & 0.250 & n.d. \\
\hline & & cyclopentenes & 0.264 & 1.616 & 1.745 & n.d. \\
\hline 9,10 & 2,88 & Cyclohexadiene, methyl & n.d. & n.d. & 0.062 & n.d. \\
\hline 10,03 & 2,99 & Cyclohexadiene, methyl & n.d. & 0.077 & n.d. & n.d. \\
\hline 10,57 & 3,10 & Cyclohexadiene, methyl & n.d. & 0.039 & n.d. & n.d. \\
\hline 11,50 & 3,26 & Cyclohexadiene, methyl & n.d. & n.d. & 0.136 & n.d. \\
\hline 12,70 & 3,24 & Cyclohexadiene, C2 & n.d. & 0.075 & n.d. & n.d. \\
\hline 12,97 & 3,32 & Cyclohexadiene, $\mathrm{C} 2$ & 1.132 & n.d. & n.d. & n.d. \\
\hline 13,37 & 3,23 & Cyclohexadiene, $\mathrm{C} 2$ & 1.294 & 0.201 & n.d. & n.d. \\
\hline 13,90 & 3,40 & Cyclohexadiene, $\mathrm{C} 2$ & n.d. & 0.609 & 0.094 & n.d. \\
\hline 14,30 & 3,43 & Cyclohexadiene, $\mathrm{C} 2$ & 1.199 & n.d. & 0.225 & n.d. \\
\hline 14,30 & 3,52 & Cyclohexadiene, $\mathrm{C} 2$ & 0.672 & 0.280 & n.d. & n.d. \\
\hline 14,70 & 3,44 & Cyclohexadiene, $\mathrm{C} 2$ & 0.812 & 0.478 & n.d. & n.d. \\
\hline 15,10 & 3,54 & Cyclohexadiene, $\mathrm{C} 2$ & 0.353 & n.d. & n.d. & n.d. \\
\hline 15,37 & 3,61 & Cyclohexadiene, $\mathrm{C} 2$ & 1.066 & 0.194 & 0.204 & n.d. \\
\hline 16,17 & 3,59 & Cyclohexadiene, C3 & n.d. & n.d. & 0.040 & n.d. \\
\hline 16,43 & 3,79 & Cyclohexadiene, C3 & n.d. & 0.408 & 0.179 & n.d. \\
\hline 16,97 & 3,83 & Cyclohexadiene, C3 & 0.175 & n.d. & 0.096 & n.d. \\
\hline 21,23 & 3,95 & Cyclohexadiene, $\mathrm{C} 4$ & 0.132 & n.d. & n.d. & n.d. \\
\hline 22,17 & 4,24 & Cyclohexadiene, C4 & n.d. & 0.120 & n.d. & n.d. \\
\hline 22,70 & 3,69 & Cyclohexadiene, C4 & n.d. & 1.064 & n.d. & n.d. \\
\hline 23,10 & 3,68 & Cyclohexadiene, C4 & 0.445 & n.d. & n.d. & n.d. \\
\hline 24,17 & 3,80 & Cyclohexadiene, $\mathrm{C} 4$ & n.d. & 0.618 & n.d. & n.d. \\
\hline \multirow[t]{2}{*}{24,70} & 4,07 & Cyclohexadiene, C4 & n.d. & 0.269 & n.d. & n.d. \\
\hline & & cyclohexadienes & 7.279 & 4.432 & 1.036 & n.d. \\
\hline 9,37 & 2.81 & Cyclohexene. methyl & 3.495 & n.d. & 0.301 & n.d. \\
\hline 10,43 & 2.95 & Cyclohexene. methyl- & 1.565 & 0.179 & 0.220 & n.d. \\
\hline 12,17 & 2.99 & Cyclohexene. C2 & 0.361 & n.d. & n.d. & n.d. \\
\hline 12,30 & 3.15 & Cyclohexene. $\mathrm{C} 2$ & 4.151 & 0.029 & n.d. & n.d. \\
\hline 14,57 & 3.29 & Cyclohexene. C2 & 0.947 & n.d. & 0.126 & n.d. \\
\hline 16,43 & 3.26 & Cyclohexene. C3 & n.d. & n.d. & 0.069 & n.d. \\
\hline 16,57 & 3.35 & Cyclohexene. C3 & 0.272 & n.d. & n.d. & n.d. \\
\hline 18,97 & 3.45 & Cyclohexene. C3 & 0.569 & 0.726 & 0.123 & n.d. \\
\hline 23,77 & 3.53 & Cyclohexene. C4 & 0.134 & 0.300 & 0.050 & n.d. \\
\hline 24,30 & 3.56 & Cyclohexene. C4 & 0.194 & n.d. & 0.099 & n.d. \\
\hline 28,97 & 3.60 & Cyclohexene. C5 & n.d. & n.d. & 0.131 & n.d. \\
\hline 29,23 & 3.64 & Cyclohexene. C5 & n.d. & n.d. & 0.062 & n.d. \\
\hline 29,37 & 3.63 & Cyclohexene. C5 & n.d. & 0.406 & n.d. & n.d. \\
\hline 31,77 & 3.60 & Cyclohexene. C5 & n.d. & 0.236 & n.d. & n.d. \\
\hline 34,03 & 3.65 & Cyclohexene. C6 & n.d. & 0.621 & n.d. & n.d. \\
\hline 34,17 & 3.69 & Cyclohexene. C6 & 0.039 & 0.212 & 0.090 & n.d. \\
\hline 38,70 & 3.77 & Cyclohexene. C7 & n.d. & 0.234 & 0.097 & n.d. \\
\hline 40,97 & 3.71 & Cyclohexene. C7 & n.d. & 0.037 & n.d. & n.d. \\
\hline 43,10 & 3.82 & Cyclohexene. C8 & n.d. & 0.075 & n.d. & n.d. \\
\hline 45,10 & 3.79 & Cyclohexene. C8 & n.d. & 0.023 & n.d. & n.d. \\
\hline 47,10 & 3.89 & Cyclohexene. C9 & n.d. & 0.078 & 0.071 & n.d. \\
\hline
\end{tabular}




\begin{tabular}{|c|c|c|c|c|c|c|c|}
\hline 49,10 & 3.85 & \multicolumn{2}{|c|}{ Cyclohexene. C9 } & n.d. & 0.037 & n.d. & n.d. \\
\hline 54,57 & 4.06 & \multicolumn{2}{|c|}{ Cyclohexene. C11 } & 0.016 & n.d. & 0.029 & n.d. \\
\hline & & \multicolumn{2}{|c|}{ cyclohexenes } & 11.745 & 3.194 & 1.466 & n.d. \\
\hline 8,97 & 2.65 & \multicolumn{2}{|c|}{ Cyclohexane. methyl- } & n.d. & 0.028 & n.d. & n.d. \\
\hline 12,83 & 3.00 & \multicolumn{2}{|c|}{ Cyclohexane. $\mathrm{C} 2$} & 0.789 & 0.075 & n.d. & n.d. \\
\hline 22,83 & 3.31 & \multicolumn{2}{|c|}{ Cyclohexane. C4 } & 0.985 & 0.549 & n.d. & 0.352 \\
\hline 28,03 & 3.40 & \multicolumn{2}{|c|}{ Cyclohexane. C5 } & 0.081 & n.d. & n.d. & n.d. \\
\hline 29,50 & 3.58 & \multicolumn{2}{|c|}{ Cyclohexane. C5 } & n.d. & 0.064 & n.d. & n.d. \\
\hline 34,43 & 3.64 & \multicolumn{2}{|c|}{ Cyclohexane. C6 } & n.d. & 0.119 & n.d. & n.d. \\
\hline 37,77 & 3.54 & \multicolumn{2}{|c|}{ Cyclohexane. C7 } & n.d. & 0.433 & n.d. & n.d. \\
\hline 40,43 & 3.53 & \multicolumn{2}{|c|}{ Cyclohexane. C7 } & n.d. & 0.053 & n.d. & n.d. \\
\hline 41,50 & 3.61 & \multicolumn{2}{|c|}{ Cyclohexane. C7 } & n.d. & 0.100 & n.d. & n.d. \\
\hline 42,17 & 3.61 & \multicolumn{2}{|c|}{ Cyclohexane. C8 } & n.d. & 0.351 & n.d. & n.d. \\
\hline 44,57 & 3.61 & \multicolumn{2}{|c|}{ Cyclohexane. C8 } & n.d. & 0.088 & n.d. & n.d. \\
\hline 46,30 & 3.68 & \multicolumn{2}{|c|}{ Cyclohexane. C9 } & n.d. & 0.257 & n.d. & n.d. \\
\hline 48,57 & 3.68 & \multicolumn{2}{|c|}{ Cyclohexane. C9 } & n.d. & 0.020 & n.d. & n.d. \\
\hline & & \multicolumn{2}{|c|}{ cyclohexanes } & 1.855 & 2.137 & n.d. & 0.352 \\
\hline \multicolumn{4}{|c|}{ total of hydrocarbons } & 84.514 & 83.502 & 87.091 & 3.342 \\
\hline \multirow{2}{*}{$\mathbf{1}_{\mathrm{tR}(\min )}$} & \multirow{2}{*}{\multicolumn{2}{|c|}{$2_{\mathrm{tR}}(\mathrm{s})$}} & iddotificotion & & area & & \\
\hline & & & Identitication & ОСН & OPL & OCL & OPH \\
\hline 12.57 & & 3.47 & Pentanoic acid, methyl ester & 0.818 & n.d. & n.d. & n.d. \\
\hline 17.37 & & 3.70 & Hexanoic acid, methyl ester & 0.025 & n.d. & n.d. & n.d. \\
\hline 22.17 & & 4.00 & Heptenoic acid, methyl ester & 0.078 & nd & nd & nd \\
\hline & & & thyl esters & 0,921 & n.d. & n.d. & n.d. \\
\hline 9.50 & & 2.96 & Pentanol & n.d. & n.d. & n.d. & 0.244 \\
\hline 10.97 & & 3.11 & Pentanol & n.d. & n.d. & n.d. & 0.007 \\
\hline 12.43 & & 3.34 & Hexanol & n.d. & 0.237 & n.d. & 2.267 \\
\hline 13.50 & & 3.72 & Hexenol & n.d. & n.d. & n.d. & 0.004 \\
\hline 19.90 & & 3.02 & Heptanol & n.d. & 0.050 & n.d. & n.d. \\
\hline 23.37 & & 3.03 & Octenol & n.d. & 0.021 & n.d. & n.d. \\
\hline 25.77 & & 3.91 & Nonenol & n.d. & 0.001 & n.d. & n.d. \\
\hline 42.30 & & 3.52 & Tridecanol & n.d. & 0.356 & n.d. & n.d. \\
\hline 17.37 & & 3.73 & Furanmethanol & n.d. & n.d. & n.d. & 8.408 \\
\hline 33.77 & & 4.41 & Phenyl hexanol & n.d. & n.d. & 0.133 & n.d. \\
\hline 42.70 & & 4.48 & Phenyl octanol & n.d. & n.d. & 0.035 & n.d. \\
\hline 37.50 & & 3.61 & Cyclopentyl propanol & n.d. & 0.160 & n.d. & n.d. \\
\hline 41.90 & & 3.70 & Cyclopentyl butanol & n.d. & 0.069 & n.d. & n.d. \\
\hline & & & alcohols & n.d. & 0,894 & 0.168 & 10.930 \\
\hline 11.77 & & 2.91 & Heptadienal & n.d. & n.d. & 0.115 & n.d. \\
\hline 17.10 & & 3.48 & Octatrienal & n.d. & 0.146 & n.d. & n.d. \\
\hline 18.43 & & 3.66 & Octatrienal & n.d. & 0.209 & n.d. & n.d. \\
\hline 21.77 & & 3.99 & Benzeneacetaldehyde, methyl & n.d. & n.d. & 0.109 & n.d. \\
\hline 26.30 & & 5.16 & Propenal, phenyl & n.d. & 0.061 & 1.065 & n.d. \\
\hline & & & Idehydes & n.d. & 0.416 & 1.289 & n.d. \\
\hline 7.63 & & 2.72 & Pentenone & n.d. & n.d. & n.d. & 0.187 \\
\hline 8.17 & & 2.91 & Pentanone & n.d. & n.d. & n.d. & 0.653 \\
\hline 8.43 & & 2.96 & Pentanone & n.d. & n.d. & n.d. & 0.986 \\
\hline 9.50 & & 3.09 & Hexanone & n.d. & n.d. & n.d. & 0.034 \\
\hline 9.63 & & 3.52 & Hexanone & 0.170 & n.d. & n.d. & n.d. \\
\hline 9.77 & & 3.19 & Hexanone & 0.106 & n.d. & n.d. & n.d. \\
\hline
\end{tabular}




\begin{tabular}{|c|c|c|c|c|c|c|}
\hline \begin{tabular}{|c|}
9.90 \\
\end{tabular} & 3.24 & Hexanone & 0.316 & n.d. & n.d. & n.d. \\
\hline 10.97 & 3.40 & Hexanone & 0.909 & n.d. & n.d. & n.d. \\
\hline 11.10 & 3.37 & Hexanone & n.d. & 0.033 & 0.047 & 0.040 \\
\hline 14.17 & 3.58 & Heptanone & n.d. & n.d. & n.d. & 0.033 \\
\hline 14.97 & 3.90 & Heptenone & 0.783 & n.d. & n.d. & n.d. \\
\hline 15.63 & 3.86 & Heptanone & 0.455 & n.d. & n.d. & n.d. \\
\hline 15.50 & 3.72 & Heptanone & n.d. & 0.406 & 0.155 & n.d. \\
\hline 15.77 & 3.75 & Heptanone & n.d. & 0.772 & 0.416 & 0.399 \\
\hline 20.57 & 3.87 & Octanone & n.d. & 0.160 & 0.101 & n.d. \\
\hline 20.83 & 3.92 & Octanone & 0.662 & 0.911 & 0.810 & 0.438 \\
\hline 25.10 & 3.84 & Nonanone & n.d. & 0.149 & n.d. & n.d. \\
\hline 26.03 & 3.96 & Nonanone & n.d. & n.d. & 1.422 & n.d. \\
\hline 25.63 & 4.20 & Nonenone & 0.631 & 0.556 & n.d. & n.d. \\
\hline 30.70 & 4.20 & Decenone & 0.134 & 0.200 & n.d. & n.d. \\
\hline 30.83 & 3.92 & Decanone & 0.094 & 0.172 & 0.125 & n.d. \\
\hline 31.10 & 3.97 & Decanone & n.d. & 0.670 & 0.651 & n.d. \\
\hline 34.70 & 3.91 & Undecanone & 0.081 & n.d. & n.d. & n.d. \\
\hline 35.50 & 3.95 & Undecanone & 0.046 & 0.126 & n.d. & n.d. \\
\hline 39.10 & 3.94 & Dodecanone & 0.069 & 0.020 & 0.121 & n.d. \\
\hline 39.77 & 4.25 & Dodecenone & 0.087 & n.d. & n.d. & n.d. \\
\hline 40.03 & 4.05 & Dodecanone & 0.112 & n.d. & n.d. & n.d. \\
\hline 50.97 & 4.06 & Tetradecanone & 0.078 & n.d. & n.d. & n.d. \\
\hline 58.70 & 4.35 & Hexadecanone & 1.477 & n.d. & n.d. & n.d. \\
\hline 61.77 & 4.31 & heptadecanone & 0.206 & n.d. & n.d. & n.d. \\
\hline 64.97 & 4.44 & Octadecanone & 0.668 & n.d. & 0.943 & n.d. \\
\hline \multicolumn{3}{|c|}{ aliphatic ketones } & 7.085 & 4.175 & 4.791 & 2.769 \\
\hline 11.32 & 4.28 & Cyclopentanone & n.d. & 0.051 & 0.144 & 1.219 \\
\hline 13.32 & 4.28 & Cyclopentanone, methyl & n.d. & 0.285 & 0.116 & 1.144 \\
\hline 13.68 & 4.35 & Cyclopentanone, methyl & n.d. & 0.180 & 0.110 & 0.584 \\
\hline 15.23 & 4.14 & Cyclopentanone, C2 & n.d. & 0.020 & n.d. & n.d. \\
\hline 15.86 & 4.28 & Cyclopentanone, C2 & 0.038 & n.d. & 0.018 & 0.176 \\
\hline 16.03 & 4.28 & Cyclopentanone, C2 & n.d. & n.d. & 0.010 & 0.056 \\
\hline 18.03 & 4.58 & Cyclopentanone, C2 & 0.555 & 0.307 & n.d. & 0.319 \\
\hline 18.17 & 4.53 & Cyclopentanone, C2 & n.d. & n.d. & 0.087 & n.d. \\
\hline 18.57 & 4.78 & Cyclopentanone, C3 & 0.237 & 0.186 & n.d. & n.d. \\
\hline 19.10 & 4.70 & Cyclopentanone, C3 & 0.175 & 0.196 & 0.081 & 0.097 \\
\hline 26.43 & 4.46 & Cyclopentanone, C4 & n.d. & 0.036 & n.d. & n.d. \\
\hline 13.99 & 5.10 & Cyclopentenone, methyl- & n.d. & n.d. & n.d. & 6.587 \\
\hline 16.70 & 5.06 & Cyclopentenone, $\mathrm{C} 2$ & n.d. & 0.220 & n.d. & n.d. \\
\hline 18.17 & 4.72 & Cyclopentenone, $\mathrm{C} 2$ & n.d. & n.d. & 0.088 & 0.859 \\
\hline 19.77 & 5.67 & Cyclopentenone, $\mathrm{C} 2$ & n.d. & n.d. & n.d. & 3.482 \\
\hline 21.28 & 5.16 & Cyclopentenone, C2 & 0.120 & 0.414 & n.d. & 2.135 \\
\hline 22.57 & 4.77 & Cyclopentenone, C3 & 0.054 & n.d. & n.d. & 0.818 \\
\hline 22.70 & 5.42 & Cyclopentenone, C3 & 0.079 & n.d. & n.d. & n.d. \\
\hline 23.47 & 5.48 & Cyclopentenone, C3 & 0.245 & 0.544 & 0.241 & 6.209 \\
\hline 24.63 & 5.01 & Cyclopentenone, C3 & 0.118 & n.d. & 0.118 & n.d. \\
\hline 25.50 & 5.69 & Cyclopentenone, C3 & n.d. & n.d. & n.d. & 0.567 \\
\hline 26.97 & 4.75 & Cyclopentenone, C4 & n.d. & 0.076 & n.d. & n.d. \\
\hline 27.50 & 4.82 & Cyclopentenone, C4 & n.d. & 0.138 & n.d. & n.d. \\
\hline 26.83 & 4.78 & Cyclopentenone, C4 & n.d. & n.d. & n.d. & 0.010 \\
\hline 31.50 & 5.51 & Cyclopentenone, C5 & n.d. & n.d. & n.d. & 0.271 \\
\hline \multicolumn{3}{|c|}{ cyclopentenones and cyclopentanones } & 1,622 & 2,653 & 1.013 & 24.532 \\
\hline
\end{tabular}




\begin{tabular}{|c|c|c|c|c|c|c|}
\hline 15.86 & 4.97 & Cyclohexanone & n.d. & 0.073 & 0.072 & 0.614 \\
\hline 18.57 & 4.79 & Cyclohexanone, methyl- & n.d. & 0.134 & 0.047 & n.d. \\
\hline 18.70 & 4.89 & Cyclohexanone, methyl- & n.d. & 0.035 & 0.023 & n.d. \\
\hline 21.10 & 5.27 & Cyclohexenone, methyl- & n.d. & 0.180 & n.d. & 1.675 \\
\hline 23.23 & 4.85 & Cyclohexanone, C2 & n.d. & 0.017 & n.d. & n.d. \\
\hline 23.37 & 4.94 & Cyclohexenone, $\mathrm{C} 2$ & n.d. & 0.005 & n.d. & n.d. \\
\hline 24.70 & 3.42 & Cyclohexanone, C3 & n.d. & 0.248 & n.d. & n.d. \\
\hline \multicolumn{3}{|c|}{ cyclohexenones and cyclohexanones } & n.d. & 0.692 & 0.143 & 2.289 \\
\hline 21.90 & 5.38 & Cycloheptanone & n.d. & 0.052 & 0.040 & 0.883 \\
\hline 35.50 & 4.50 & Pentenone, phenyl- & 0.045 & n.d. & n.d. & n.d. \\
\hline 38.17 & 4.25 & Pentanone, methyl phenyl- & 0.021 & n.d. & n.d. & n.d. \\
\hline 25.20 & 5.56 & Acetophenone & 0.315 & 0.009 & 0.035 & 0.144 \\
\hline 30.30 & 5.57 & Acetophenone, methyl & n.d. & n.d. & 0.087 & n.d. \\
\hline 20.83 & 4.51 & Cyclohexyl, methyl ketone & n.d. & n.d. & 0.271 & n.d. \\
\hline 22.70 & 4.74 & Ethanone, cyclohexenyl & n.d. & 0.076 & 0.027 & n.d. \\
\hline 24.70 & 4.99 & Ethanone, methyl cyclopentenyl- & n.d. & 0.262 & n.d. & n.d. \\
\hline 26.03 & 5.23 & Cyclohexenyl, methyl ketone & n.d. & n.d. & 0.119 & 0.101 \\
\hline 37.50 & 6.81 & Indenone, hexahydro- & n.d. & n.d. & n.d. & 0.109 \\
\hline \multicolumn{3}{|c|}{ othersketones } & 0.381 & 0.400 & 0.579 & 1.237 \\
\hline 8.57 & 2.88 & Furan. dimethyl- & 0.591 & n.d. & n.d. & n.d. \\
\hline 9.23 & 2.75 & Ethane. diethoxy- & n.d. & n.d. & n.d. & 2.003 \\
\hline 12.17 & 3.32 & Furan. trimethyl- & 0.068 & n.d. & n.d. & n.d. \\
\hline 21.14 & 5.08 & Benzofuran & 0.474 & n.d. & 0.132 & 4.260 \\
\hline 26.57 & 5.13 & Benzofuran. methyl- & 0.326 & n.d. & n.d. & n.d. \\
\hline 26.83 & 5.16 & Benzofuran. methyl & n.d. & n.d. & 0.231 & n.d. \\
\hline 30.57 & 5.15 & Benzofuran. C2 & n.d. & n.d. & 0.039 & n.d. \\
\hline 31.37 & 5.16 & Benzofuran. C2 & n.d. & n.d. & 0.044 & n.d. \\
\hline 33.23 & 5.40 & Benzofuran. C2 & n.d. & n.d. & 0.021 & n.d. \\
\hline \multicolumn{3}{|r|}{ ethers } & 1.459 & n.d. & 0.468 & 6.263 \\
\hline 22.20 & 4.36 & Phenol & 0.347 & 0.655 & 0.987 & 2.020 \\
\hline 24.77 & 4.83 & Phenol, methyl- & n.d. & 1.931 & n.d. & 0.057 \\
\hline 25.63 & 4.57 & Phenol, methyl- & n.d. & n.d. & 0.517 & n.d. \\
\hline 26.57 & 4.62 & Phenol, methyl- & n.d. & n.d. & 0.243 & 0.781 \\
\hline 26.83 & 5.20 & Phenol, C2 & 0.395 & n.d. & n.d. & n.d. \\
\hline 28.70 & 4.94 & Phenol, C2 & 1.161 & n.d. & n.d. & n.d. \\
\hline 28.83 & 4.89 & Phenol, C2 & n.d. & n.d. & 0.472 & n.d. \\
\hline 28.97 & 4.05 & Phenol, C2 & n.d. & 0.432 & n.d. & n.d. \\
\hline 29.23 & 4.99 & Phenol, C2 & 0.538 & 1.425 & n.d. & n.d. \\
\hline 29.37 & 4.94 & Phenol, C2 & n.d. & n.d. & 1.112 & n.d. \\
\hline 30.57 & 5.09 & Phenol, C2 & 0.357 & 0.963 & n.d. & n.d. \\
\hline 30.70 & 4.98 & Phenol, C2 & 0.021 & 0.152 & 0.431 & n.d. \\
\hline 31.63 & 5.22 & Phenol, C3 & 0.147 & 0.244 & 0.170 & n.d. \\
\hline 32.70 & 4.93 & Phenol, C3 & 0.304 & n.d. & n.d. & n.d. \\
\hline 32.97 & 5.01 & Phenol, C3 & 0.279 & n.d. & n.d. & n.d. \\
\hline 32.97 & 5.43 & Phenol, C3 & 0.172 & 0.151 & 0.147 & n.d. \\
\hline 33.17 & 4.95 & Phenol, C3 & n.d. & 0.303 & 0.192 & n.d. \\
\hline 33.50 & 5.08 & Phenol, C3 & n.d. & 0.135 & 0.187 & n.d. \\
\hline 33.63 & 5.04 & Phenol, C3 & n.d. & 0.032 & n.d. & n.d. \\
\hline 34.97 & 5.26 & Phenol, C3 & 0.165 & n.d. & n.d. & n.d. \\
\hline 35.10 & 5.19 & Phenol, C4 & 0.081 & 0.360 & n.d. & n.d. \\
\hline 35.77 & 5.24 & Phenol, C4 & 0.009 & 0.025 & n.d. & n.d. \\
\hline
\end{tabular}




\begin{tabular}{|c|c|c|c|c|c|c|}
\hline 36.70 & 5.08 & Phenol, C4 & 0.044 & n.d. & n.d. & n.d. \\
\hline \multicolumn{3}{|r|}{ phenols } & 4,018 & 6,809 & 4.458 & 2.858 \\
\hline 11.37 & 2.91 & Piperidine, methyl- & n.d. & n.d. & n.d. & 0.013 \\
\hline 11.50 & 2.88 & Piperidine, methyl- & n.d. & n.d. & n.d. & 0.145 \\
\hline 15.37 & 4.06 & Piperidine, C2 & n.d. & 0.218 & n.d. & 0.093 \\
\hline 27.23 & 4.88 & Piperidinone, C4 & n.d. & n.d. & n.d. & 0.248 \\
\hline \multicolumn{3}{|c|}{ pyperidines } & n.d. & 0,218 & n.d. & 0.499 \\
\hline 16.43 & 4.47 & Pyrazine, C2 & n.d. & n.d. & n.d. & 0.038 \\
\hline 16.83 & 4.62 & Pyrazine, C2 & n.d. & n.d. & n.d. & 0.574 \\
\hline 16.83 & 4.66 & Pyrazine, C2 & n.d. & n.d. & n.d. & 0.153 \\
\hline 17.23 & 4.72 & Pyrazine, $\mathrm{C} 2$ & n.d. & n.d. & n.d. & 0.067 \\
\hline 21.23 & 4.72 & Pyrazine, C3 & n.d. & n.d. & n.d. & 0.143 \\
\hline 21.50 & 4.76 & Pyrazine, C3 & n.d. & n.d. & n.d. & 2.781 \\
\hline 25.37 & 4.67 & Pyrazine, C4 & n.d. & n.d. & n.d. & 1.467 \\
\hline 25.63 & 4.72 & Pyrazine, C4 & n.d. & n.d. & n.d. & 2.690 \\
\hline 25.77 & 4.81 & Pyrazine, C4 & n.d. & n.d. & n.d. & 8.311 \\
\hline 29.50 & 4.68 & Pyrazine, C5 & n.d. & n.d. & n.d. & 8.063 \\
\hline 29.90 & 4.65 & Pyrazine, C5 & n.d. & n.d. & n.d. & 0.204 \\
\hline 30.17 & 4.74 & Pyrazine, C5 & n.d. & n.d. & n.d. & 0.107 \\
\hline 33.37 & 4.60 & Pyrazine, C5 & n.d. & n.d. & n.d. & 0.309 \\
\hline \multicolumn{3}{|r|}{ pyrazines } & n.d. & n.d. & n.d. & 24.907 \\
\hline 33.23 & 5.02 & Pyrazole, C3 & n.d. & n.d. & n.d. & 0.402 \\
\hline 33.37 & 5.77 & Pyrazole, C4 & n.d. & n.d. & n.d. & 0.150 \\
\hline 34.70 & 5.38 & Pyrazole, C5 & n.d. & n.d. & n.d. & 0.565 \\
\hline 35.37 & 5.15 & Pyrazole, C4 & n.d. & n.d. & n.d. & 1.685 \\
\hline \multicolumn{3}{|c|}{ pyrazoles } & n.d. & n.d. & n.d. & 2.802 \\
\hline 9.63 & 3.56 & Pyrrole & n.d. & n.d. & n.d. & 0.035 \\
\hline 10.43 & 3.74 & Pyrrole, methyl- & n.d. & n.d. & n.d. & 9.287 \\
\hline 26.83 & 6.03 & Pyrrolidinone, $\mathrm{C} 2$ & n.d. & n.d. & n.d. & 0.053 \\
\hline 27.77 & 6.25 & pyrrolidinone, $\mathrm{C} 2$ & n.d. & n.d. & n.d. & 0.699 \\
\hline 36.17 & 6.67 & Pyrrolidinone, C3 & n.d. & n.d. & n.d. & 0.775 \\
\hline \multicolumn{3}{|c|}{ pyrroles } & n.d. & n.d. & n.d. & 10.849 \\
\hline 12.83 & 3.99 & Pyridine, methyl- & n.d. & n.d. & n.d. & 0.669 \\
\hline 15.23 & 4.32 & Pyridine, methyl- & n.d. & n.d. & n.d. & 1.355 \\
\hline 15.50 & 4.18 & Pyridine, $\mathrm{C} 2$ & n.d. & n.d. & n.d. & 0.918 \\
\hline 16.57 & 4.35 & Pyridine, $\mathrm{C} 2$ & n.d. & n.d. & n.d. & 0.170 \\
\hline 16.70 & 4.35 & Pyridine, $\mathrm{C} 2$ & n.d. & 0.035 & n.d. & n.d. \\
\hline 18.30 & 4.38 & Pyridine, $\mathrm{C} 2$ & n.d. & n.d. & n.d. & 0.112 \\
\hline 18.43 & 4.37 & Pyridine, $\mathrm{C} 2$ & n.d. & 0.039 & n.d. & n.d. \\
\hline 18.83 & 4.60 & Pyridine, $\mathrm{C} 2$ & n.d. & 0.036 & n.d. & 0.073 \\
\hline 19.50 & 4.32 & Pyridine, C3 & n.d. & n.d. & n.d. & 0.056 \\
\hline 21.10 & 4.42 & Pyridine, C3 & n.d. & n.d. & n.d. & 0.094 \\
\hline 21.77 & 4.58 & Pyridine, C3 & n.d. & n.d. & n.d. & 0.052 \\
\hline 34.97 & 5.48 & Pyridine, C5 & n.d. & n.d. & n.d. & 0.405 \\
\hline \multicolumn{3}{|r|}{ pyridines } & n.d. & 0.110 & n.d. & 3.902 \\
\hline 28.30 & 5.23 & Pentanamide. methyl- & n.d. & n.d. & n.d. & 1.055 \\
\hline 15.77 & 3.96 & Imidazole. C4 & n.d. & n.d. & n.d. & 0.117 \\
\hline 31.23 & 5.45 & Imidazole. C5 & n.d. & n.d. & n.d. & 0.088 \\
\hline 33.50 & 5.71 & Imidazole. C5 & n.d. & n.d. & n.d. & 1.561 \\
\hline 36.97 & 6.67 & Indole & n.d. & 0.136 & n.d. & n.d. \\
\hline \multicolumn{3}{|c|}{ others N-compounds } & n.d. & 0.136 & n.d. & 2.820 \\
\hline \multicolumn{3}{|c|}{ total of polarcompounds } & 15,486 & 16,502 & 12.909 & 96.658 \\
\hline
\end{tabular}

